\title{
Understanding the Impacts of Crude Oil and its Induced Abiotic Stresses on Agrifood Production: A Review
}

\author{
Johnson Odukoya ${ }^{1,2}$, , Ronnie Lambert ${ }^{1}$ and Ruben Sakrabani ${ }^{1, *}$ \\ 1 School of Water, Energy and Environment, Cranfield University, Cranfield MK43 0AL, UK; \\ joodukoya@futa.edu.ng (J.O.); rjwlambert@gmail.com (R.L.) \\ 2 Chemistry Department, The Federal University of Technology, PMB 704 Akure, Ondo State, Nigeria \\ * Correspondence: r.sakrabani@cranfield.ac.uk
}

Received: 16 February 2019; Accepted: 17 June 2019; Published: 23 June 2019

\begin{abstract}
In many parts of the world, the agricultural sector is faced with a number of challenges including those arising from abiotic environmental stresses which are the key factors responsible for most reductions in agrifood production. Crude oil contamination, an abiotic stress factor and a common environmental contaminant, at toxic levels has negative impacts on plants. Although various attempts have been made to demonstrate the impact of abiotic stresses on crops, the underlying factors responsible for the effects of crude oil and its induced abiotic stresses on the composition of the stressed plants are poorly understood. Hence, this review provides an in-depth examination of the: (1) effect of petroleum hydrocarbons on plants; (2) impact of abiotic environmental stresses on crop quality; (3) mechanistic link between crude oil stress and its induced abiotic stresses; as well as (4) mode of action/plant response mechanism to these induced stresses. The paper clearly reveals the implications of crude oil-induced abiotic stresses arising from the soil-root-plant route and from direct application on plant leaves.
\end{abstract}

Keywords: agrifood; crude oil contamination; crop quality; environmental stresses; petroleum hydrocarbons; stressed plants

\section{Introduction}

Crude oil pollution, arising from exploration and processing operations, is a common environmental challenge [1]. This introduction of crude oil (via large or small spills) into the environment could arise from technical errors, deliberate human acts as well as transportation and storage faults [2-6]. Schmidt-Etkin [7] noted that although large spills sometimes occur with serious environmental and socioeconomic damage, small spills are more common. As explained in detail in a later section, the impacts and damages caused by these spills generally depend on the location, oil type, volume, closeness to sensitive resources, and season, among other factors [7]. Nonetheless, accidental large-scale oil spills make up a significant part of contaminants in the globe [8]. There are more cases of oil spills on land than those recorded in water [4] in which plant life in agricultural fields becomes exposed to petroleum hydrocarbons (PH) [8] with both acute and chronic effects on agricultural produce [1].

Interestingly, the various technological/prevention measures coupled with better industry practices have helped in the global reduction in oil spillage but the risk involved in significant oil spills remain [7]. Table 1 provides a record of the largest oil spill cases in the world's history. 
Table 1. The top 20 largest oil spills (>125,000 tonnes) in world's history.

\begin{tabular}{|c|c|c|c|c|}
\hline $\mathrm{S} / \mathbf{N}$ & Location & Source Name & Quantity (Tonnes) & Date \\
\hline 1. & Kuwait & 700 oil wells & $71,428,571$ & 10 March 1991 \\
\hline 2. & Kuwait & Min al Ahmadi Terminal & 857,143 & 20 January 1991 \\
\hline 3. & Russia & Oil wells & 700,000 & 3 August 2000 \\
\hline 4. & United States & Deepwater Horizon & 686,000 & 20 April $2010 *$ \\
\hline 5. & Mexico & Ixtoc I well & 476,190 & 3 June 1979 \\
\hline 6. & Iraq & Bahra oil fields & 377,537 & 1 February 1991 \\
\hline 7. & Uzbekistan & Oil well & 299,320 & 2 March 1990 \\
\hline 8. & Trinidad/Tobago & TN Atlantic Express & 286,354 & 19 July 1979 \\
\hline 9. & Russia & Kharyaga-Usink Pipeline & 285,714 & 25 October 1994 \\
\hline 10. & Iran & No. 3 Well (Nowruz) & 272,109 & 4 February 1983 \\
\hline 11. & South Africa & TN Castillo de Bellver & 267,007 & 6 August 1983 \\
\hline 12. & France & TN Amoco Cadiz & 233,565 & 16 March 1978 \\
\hline 13. & Canada & TN Odyssey & 146,599 & 10 November 1988 \\
\hline 14. & Italy & TN Haven & 144,000 & 11 April 1991 \\
\hline 15. & Libya & D-103 concession well & 142,857 & 1 August 1980 \\
\hline 16. & Nigeria & Pipeline & 142,857 & 6 January 2001 \\
\hline 17. & Kuwait & TN Al Qadasiyah & 139,690 & 19 January 1991 \\
\hline 18. & Kuwait & TN Hileen & 139,690 & 19 January 1991 \\
\hline 19. & United Kingdom & TN Torrey Canyon & 129,857 & 18 March 1967 \\
\hline 20. & Oman & TN Sea Star & 128,891 & 19 December 1972 \\
\hline
\end{tabular}

* From Ivshina et al. [4] as well as Levy and Gopalakrishnan [9]; others adapted from Schmidt-Etkin [7].

Although the effect of $\mathrm{PH}$ such as from crude oil spills in the environment has been studied for many years, even with respect to the impact on plants, there is still a gap in understanding how the composition of the affected plants is influenced. Some researchers, such as Levy and Gopalakrishnan [9], Okpokwasili and Odokuma [10], Njoku et al. [11], and Ylitalo et al. [12], have reported the effect of crude oil spills on the general environment while others like Venosa et al. [13], Ebuehi et al. [14], Couto et al. [15], as well as Adekunle [16], have indicated how the remediation of such polluted sites can be carried out. Various remediation approaches, including bioremediation, have been suggested.

Evaluation of the effect of crude oil on plant growth/yield has also gained attention and the outcome of such investigations have been documented in Kuhn et al. [17], Adam and Duncan [18], Adieze et al. [19], Inckot et al. [20], Baruah et al. [21], as well as Odukoya et al. [22,23]. Nonetheless, the effects of crude oil on the composition and quality of crops still remain unclear. In most cases, such as in Baruah et al. [21], Chupakhina and Maslennikov [24], and Noori et al. [25], the impact of crude oil on only a few crop quality parameters was investigated.

Considering the human dependence on agricultural produce for food, this review provides needed information on the impact of crude oil-induced abiotic stresses on plant composition. It discusses the general impact of abiotic environmental stresses on the composition of agricultural produce (particularly with respect to crop quality), and summarises the relationship between these stresses (i.e., crude oil stress and its induced abiotic stresses) via a mechanistic link to provide clarity on the response patterns observed in crude oil-stressed plants. A chemical classification of petroleum hydrocarbons is provided in Figure 1. 


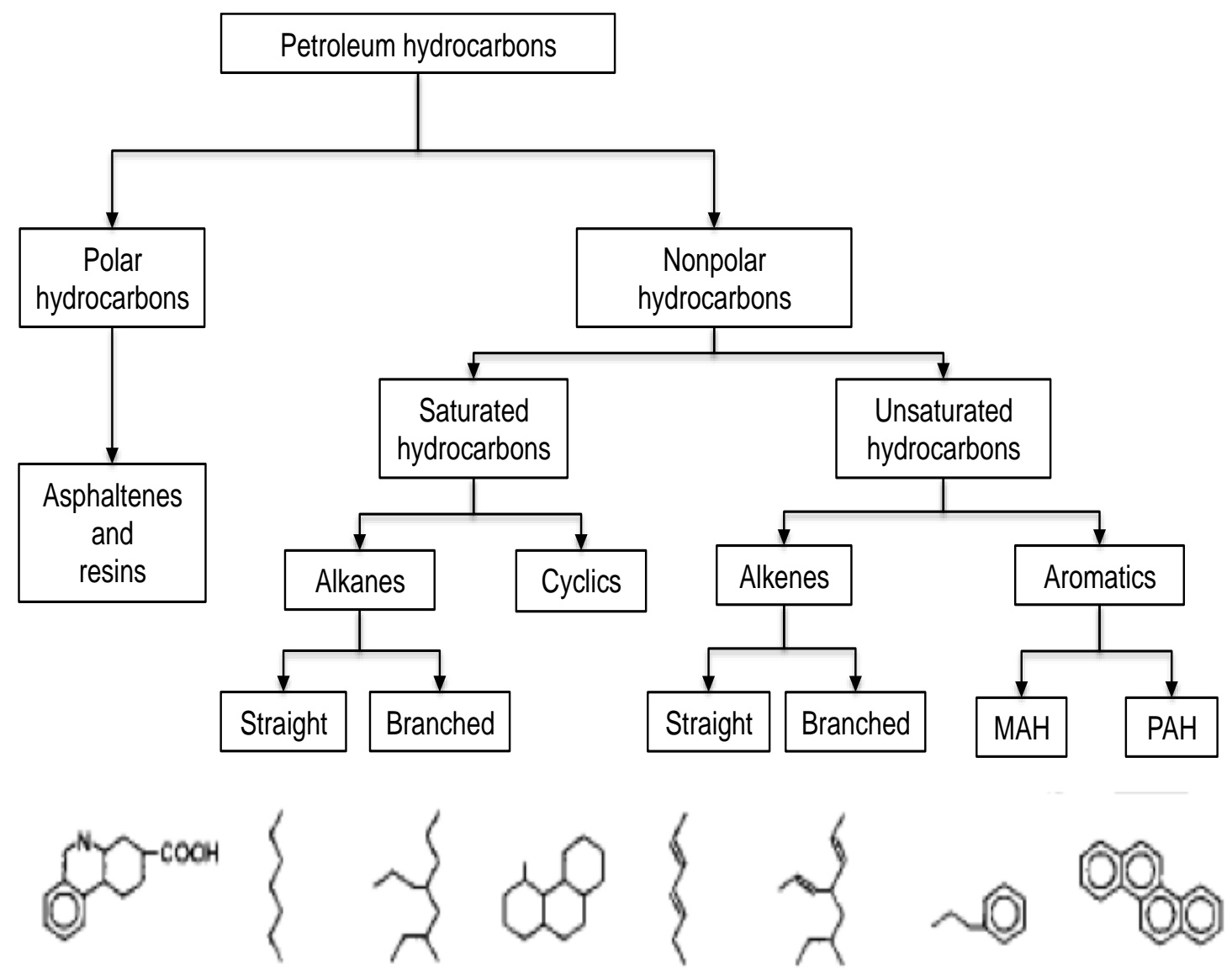

Figure 1. Chemical classification of petroleum hydrocarbons. (MAH = Monoaromatic hydrocarbons; $\mathrm{PAH}=$ Polycyclic aromatic hydrocarbons). Source: Coulon and $\mathrm{Wu}$ [26].

\section{Effects of PH on the Growing Environment and Plants}

The behaviour of $\mathrm{PH}$ in the environment determines where they are likely to be found, such as in air, water, soil, sediment, food, or other media that people might come in contact with [27]. In the view of Oghenejoboh et al. [28], the factors governing the spread/migration of spilled oil in soil include the amount of oil spilled, physical properties of the spilled oil (density and viscosity), and physical properties of the soil medium itself, particularly its porosity. Although the introduction of $\mathrm{PH}$ affects the physical, chemical, and biological properties of soil [7], these factors (i.e., the soil type, quantity, and composition of the spilled hydrocarbon) also determine the level of alteration of the soil properties $[27,29]$.

On agricultural lands, Plice [30] and also De Jong [31], reported that oil spills can result in reduced plant growth for some time. PH contamination which is associated with an increase in carbon/nitrogen $(\mathrm{C} / \mathrm{N})$ ratio and nitrogen deficiency [32], may also lead to a reduction in plant stem height, stem density, aboveground biomass, and include death of the plant [33-37]. Meanwhile, the response of plants to the presence of $\mathrm{PH}$ in soil varies [20,38,39] and is associated with the plant age [40], species of the plant involved, type and concentration of the petroleum, time of exposure to the contaminant $[20,29,38]$ as well as the season $[36,41]$, among other factors.

De Jong [31], referring to the experiment of Carr [42], indicated the possibility of a low concentration of crude oil in the environment supporting plant growth. Although this test was conducted in duplicate, Carr [42] found out that at $0.75 \% w / w$ of crude oil addition to the soil, the growth of soybeans was improved. Adieze et al. [19] also recorded an increase in shoot height and weight of two of the plant species examined at $1 \% w / w$ oil-in-soil. This stimulating effect according to Plice [30] may be as a result of the bacterial breakdown of the hydrocarbons. Other possible reasons for plant growth-stimulation, 
as suggested by Baker [38], although subject to further investigation, could be attributed to the release of nutrients from the oil, oil-killed vegetation, or hormonal influence. Be that as it may, there are claims that this occurrence in plants is a result of 'petroleum auxin' identified as naphthenic acids, which (i) improve the yield of different varieties of crops; (ii) stimulates photosynthesis; and (iii) increases protein nitrogen [38].

Notwithstanding possible positive effects, most studies regarding the growth of plants in soil containing PH have reported negative effects [20] including on the germination of seeds [18,20]. Reductions in the plant growth could be a result of (1) the direct toxic effect of oil on plants [31,38]; (2) absence of viable seeds leading to lack of germination; (3) reduced germination; (4) unfavourable soil conditions [31]; and (5) inhibition of bacterial decomposition of the soil organic matter and associated nutrient remineralization by the toxic components of oil [40]. The inhibition of germination may be linked to oil entering the seed and killing the embryo, or oil coating the seed and hindering the uptake of oxygen and water required for germination [38]. Merkl et al. [32] added that reduced seedling emergence could be as a result of toxic effects of the oil or from the adverse soil moisture conditions. Other effects of oil pollution on plants as stated by Baker [38] include yellowing and death of oiled leaves, varying sensitivity, and recovery rates of perennials, among others, while a complete elimination may occur at chronic levels. Heavier oils compared to lighter oils present less immediate toxic impact on plants and other organisms [40].

Baker [38] indicated that photosynthetic rate is consistently reduced by oils, while the level of reduction in this rate depends on the kind and amount of oil as well as the plant species. For instance, the experiment of Odukoya [5] involving selected green leafy vegetables (GLV) and a fruit vegetable (tomato (Solanum lycopersicum) indicated that the effect of crude oil contamination on the species differed. Generally, crude oil at the concentration used in this experiment $\{\leq 10,000 \mathrm{mg} / \mathrm{kg}$ total petroleum hydrocarbons (TPH) $\}$ altered stomatal conductance (a measure of the rate of diffusion of carbon dioxide $\left(\mathrm{CO}_{2}\right)$ into leaves for photosynthesis, and water loss via transpiration [43]), growth, yield, and composition of the GLV. Figures 2 and 3 show the impact of the crude oil contamination on the stomatal conductance $\left(\mathrm{mmol} / \mathrm{m}^{2} \mathrm{~s}\right)$ as well as growth of Brassica juncea, Brassica oleracea, and Lactuca sativa. The effect on the flower production date of $B$. juncea is also provided in Figure 4 . The influence on yield and levels of phytochemicals in the selected GLV has been previously discussed (see Odukoya et al. [23]).

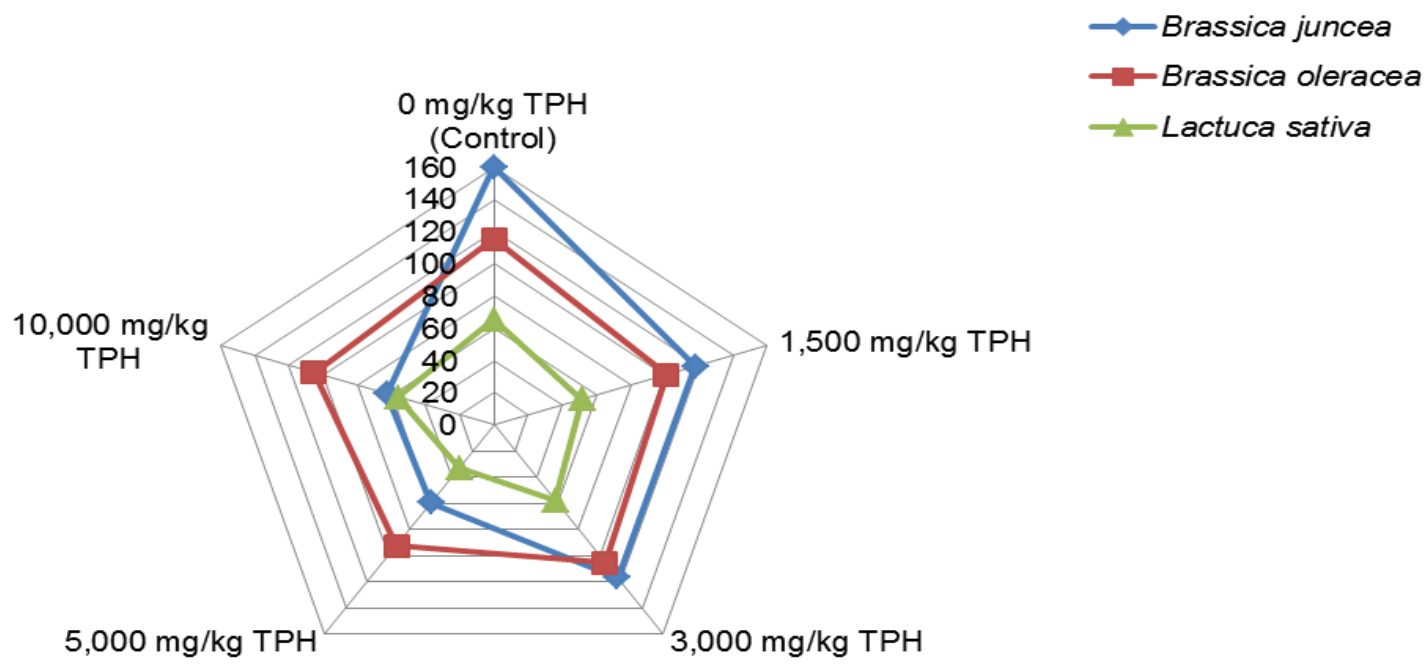

Figure 2. Effect of crude oil contamination on stomatal conductance $\left(\mathrm{mmol} / \mathrm{m}^{2} \mathrm{~s}\right)$ of selected green leafy vegetables prior to harvest. Source: Odukoya [5]. 

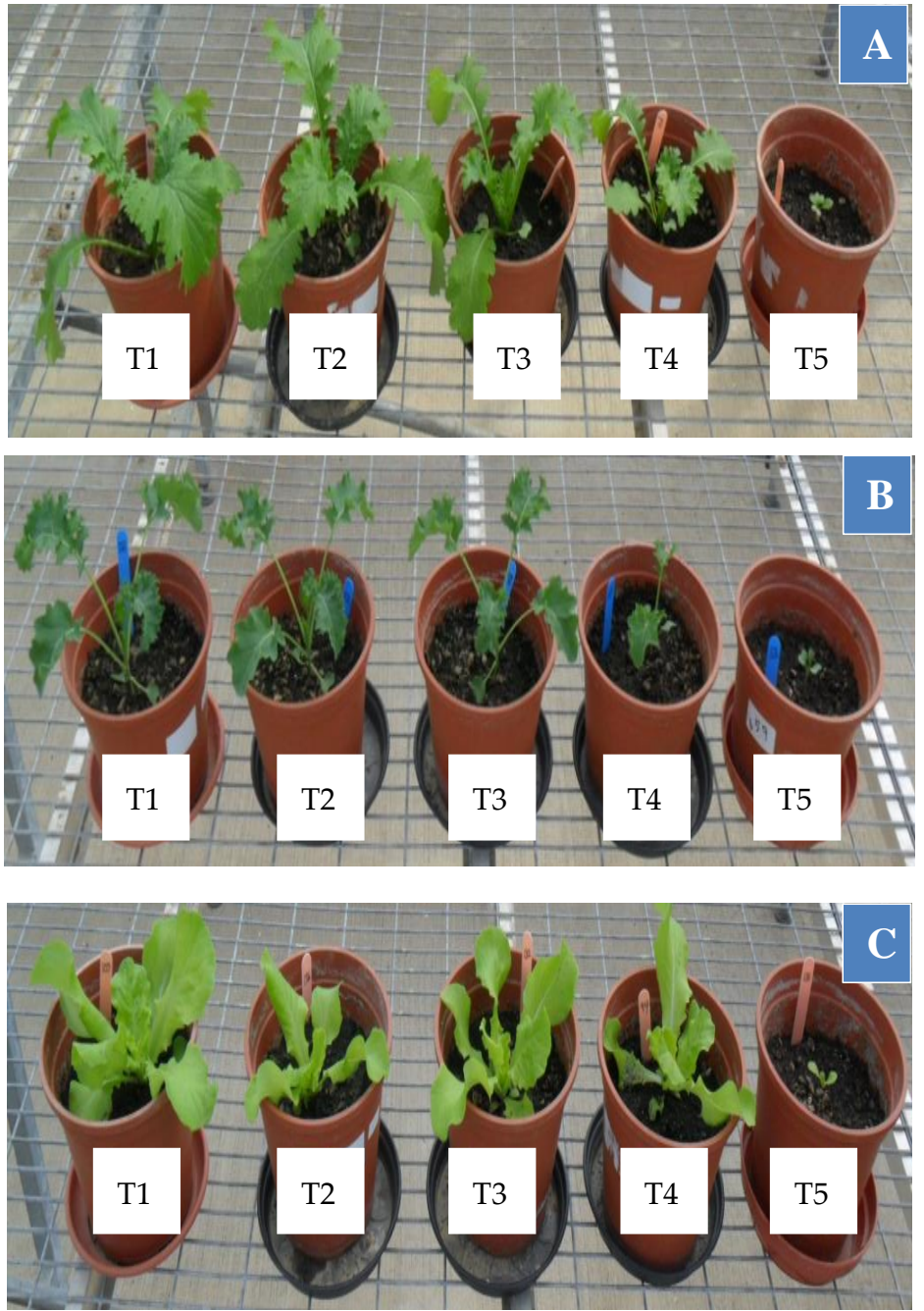

Figure 3. The growth of three green leafy vegetables ((A) B. juncea, (B) B. oleracea and (C) L. sativa) in pots containing crude oil at different concentrations. Treatments T1, T2, T3, T4 and T5 are $0 \mathrm{mg} / \mathrm{kg} \mathrm{TPH}$ (Control), $1500 \mathrm{mg} / \mathrm{kg} \mathrm{TPH,} 3000 \mathrm{mg} / \mathrm{kg} \mathrm{TPH}, 5000 \mathrm{mg} / \mathrm{kg}$ TPH, and 10,000 mg/kg TPH, respectively. Source: Odukoya [5].

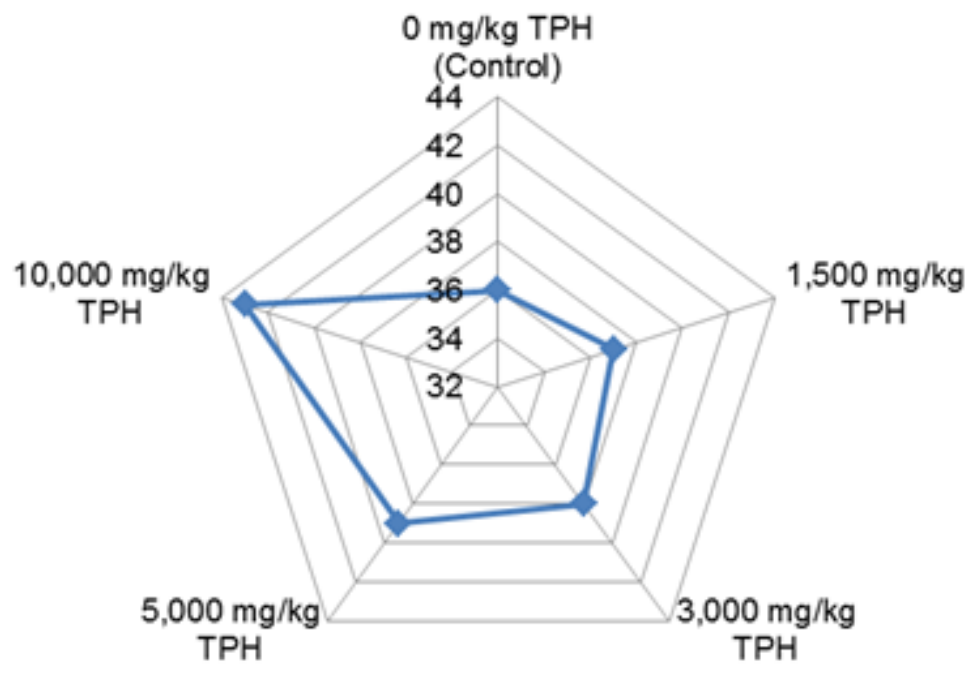
$\longrightarrow$ Average number of days required for flower production

Figure 4. The effect of crude oil contamination on flower production date of B. juncea. Source: Odukoya [5]. 
Odukoya et al. [5,22] also recorded that crude oil contamination at concentration as low as $5000 \mathrm{mg} / \mathrm{kg}$ TPH affected the growth, yield, fruit production, and ripening of Micro-Tom tomato fruits (Figure 5).
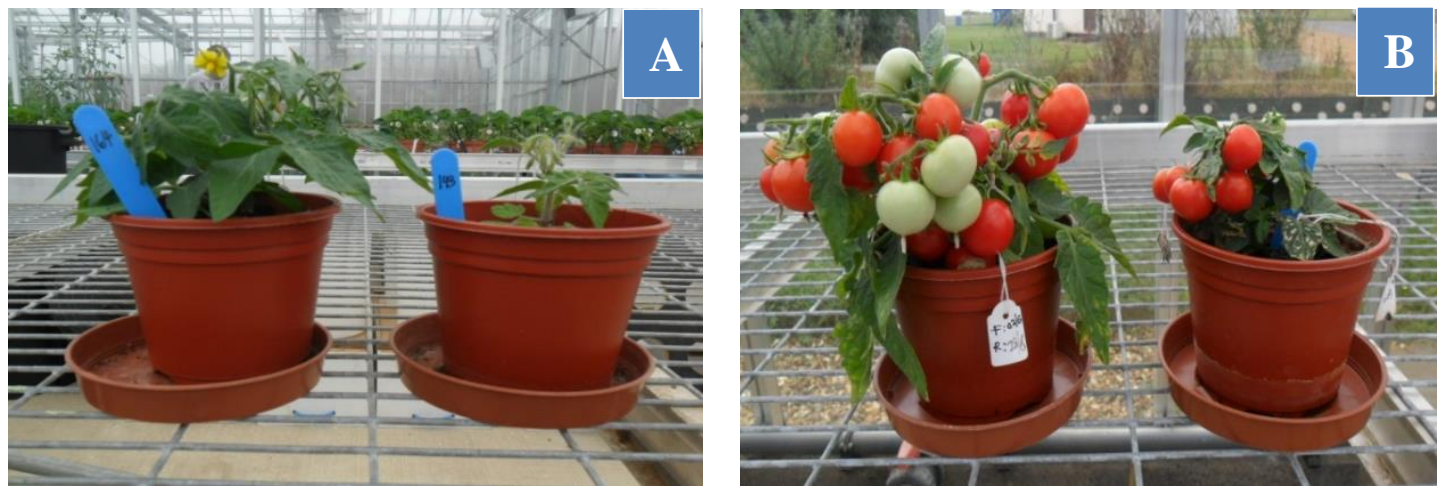

Figure 5. Growth of Micro-Tom tomatoes in pots containing crude oil at $0 \mathrm{mg} / \mathrm{kg}$ TPH (left plant) and $5000 \mathrm{mg} / \mathrm{kg} \mathrm{TPH}$ (right plant), before fruiting (A) and during ripening (B). Source: Odukoya [5].

Considering the effect of time of spillage on plant response, Baker [38] reported that application of an emulsion of light oil on young plants in the light when the stomata are opened will lead to death of the plant while the same application at night when the stomata are closed would not harm them. Baker [38] also indicated that there is an increased level of phytotoxic risk at high environmental temperature (such as during sunny or hot weather) compared to other times.

\section{Abiotic Environmental Stresses and Crop Quality}

Abiotic stresses, which include environmental contaminants [44], have been identified as the key factors responsible for most of the reduction in agrifood production (Figure 6); they also play a major role in determining the nutritional value/quality of fruits and vegetables during their growth, harvesting, handling, storage, and transport to end users [45]. The impact made by these abiotic stresses have been found to depend on the (1) the part (tissue or organ) of the plants involved [45,46]; (2) crop species; (3) duration; as well as (4) intensity of the stress [47] and could cause morphological, physiological, biochemical, and molecular alterations within the affected plants [45]. Retardation of plant growth may also occur as the plants make efforts to conserve and reallocate resources that can become limited under extreme stress conditions [48].

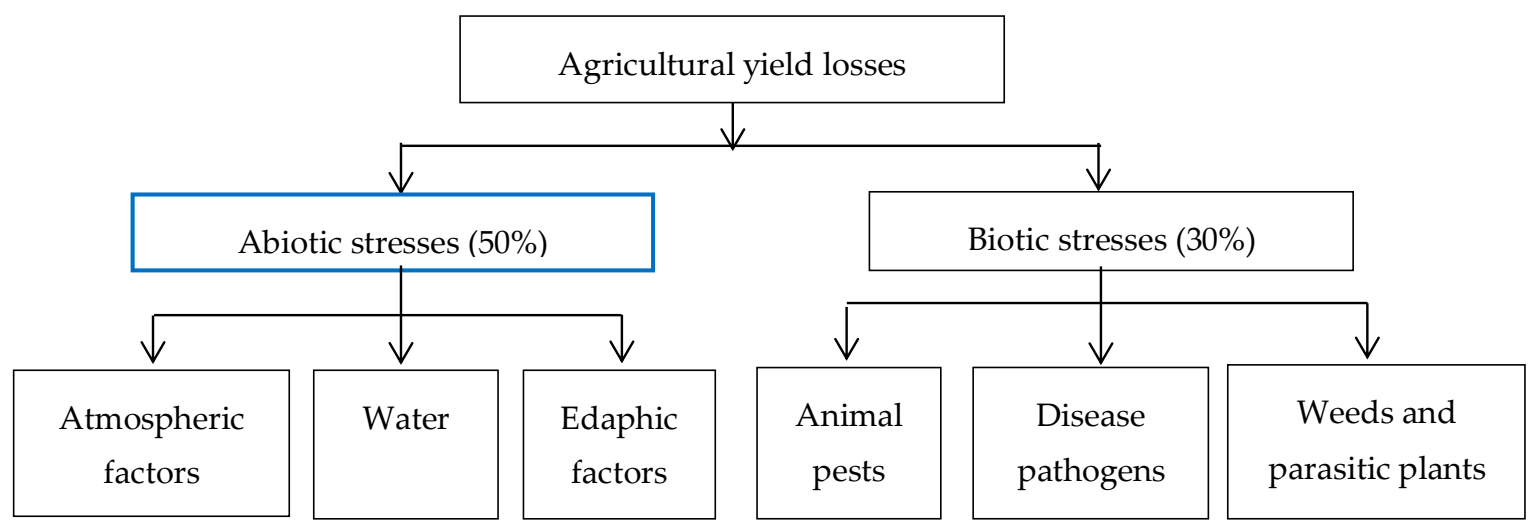

Figure 6. Agricultural yield losses due to abiotic and biotic stress. Adapted from: Gaur and Sharma [49].

Wang and Frei [47] indicated that all quality traits of agricultural produce can be influenced by abiotic environmental stress factors which can be linked with the different physiological reactions/responses in the affected plants as a result of changes in gene expression and enzyme 
activity, oxidative stress arising from the accumulation of reactive oxygen species (ROS), accelerated senescence, which shortens the crop maturity period and alters the nutrient distribution processes within the stressed plants, reduced water content which leads to increase in nutrient content, changes in mineral uptake and translocation, as well as reduced biomass/yield which is the most obvious and identified effect of abiotic environmental stress on agricultural produce. Although some crops respond differently, in most cases, environmental stresses cause (1) a decrease in starch concentration, lipids \{particularly the polyunsaturated fatty acids (PUFA)\}, feed value, and physical/sensory (P/S) traits; (2) an increase in protein and antioxidant contents; and (3) no clear trend in sugar and mineral contents [47].

On the other hand, one of the common mechanisms by which plants adapt to abiotic stresses encountered in the environment involves the accumulation of compatible solutes which are highly soluble and low molecular weight compounds with no toxic effect at high concentrations [50]. The different forms of these compounds accumulated may be species-specific and include amino acids (like proline), glycine betaine, sugars (such as sucrose, and trehalose), and sugar alcohols (like sorbitol and mannitol) [50-52]. These compatible solutes do not interfere with normal cellular metabolism [52,53].

\section{Mechanistic Link between Crude Oil Contamination and Induced Abiotic Stresses}

\subsection{Induced Physical Influence}

The coating of plant leaves with oil may lead to temperature stress owing to the blockage of the transpiration pathways while the process of photosynthesis in the leaves would be negatively affected $[40,54]$. The penetration of oxygen into the soil could also be restrained by the layer of oil covering the soil surface resulting in anaerobic soil conditions for the plant roots $[20,40]$ and contributes to oxygen stress on these roots [40].

Nevertheless, the level of reduction in transpiration and photosynthesis arising from the physical blockage of the stomata depend on the extent of oil covering on the plant which is associated with the hydrologic conditions, amount, type, and dispersion ability of the spilled oil [40].

\subsection{Induced Chemical Influence}

The chemical impact of oils on vegetation depends on the type of oil while the fouling of leaves by oil may have more immediate effects than fouling of the soil surface [40]. Pezeshki et al. [40] reported that reduced stomatal conductance with no detectable photosynthetic activity was evident shortly after leaf fouling which suggests potential breakdown of the photosynthetic apparatus in the leaves directly subjected to oil application. In their view, this breakdown of leaf structure and/or the chlorophyll system may be associated with blocked stomata giving rise to reduced transpiration, thus increasing the leaf temperature with the possibility of an adverse effect of the oil on cellular integrity of the leaf tissue. They added that plants may recover from the initial, short-term (often dramatic) adverse effects of oil on leaves while refined products, compared to crude oils, present a different effect on leaves.

Furthermore, as plants like other organisms produce ROS in response to abiotic and biotic stresses [55], environmental contamination arising from $\mathrm{PH}$ reduce the availability of essential nutrients (like nitrogen and oxygen) required for plant growth [19,56], including water [57] owing to the surface covering of the plant roots by the hydrophobic contaminant, thereby enhancing the production of ROS and hence, oxidative stress in plants $[55,58]$.

Basically, PH may affect plants by (1) upsetting the plant-water relationships; (2) direct effect on plant metabolism such as nutrient uptake [36]; (3) their toxicity to living cells [26,59]; and (4) the reduction in oxygen exchange between the atmosphere and the soil which have negative effects on plants $[36,60]$. 


\subsection{The Mechanistic Link}

Crude oil/PH contamination, an abiotic factor [61], leads to oxidative stress in plants [25] and gives rise to the production of ROS. Figure 7 shows the mechanistic link between crude oil contamination/stress and identified crude oil-induced abiotic stresses.

\section{The Mode of Action/Plant Response Mechanisms to the Crude Oil-Induced Abiotic Stresses}

\subsection{Water (Drought) and Osmotic Stresses}

"Drought is a meteorological term for a scarcity of water" ([62], p. 510) while water stress on plants occurs when there is a limitation of water supply to the roots, or when the transpiration rate exceeds the absorption rate $[45,63]$. Photosynthesis and growth are among the key processes affected by drought $[64,65]$ whose effects can: (1) be direct, such as resulting from the alteration in the diffusion of $\mathrm{CO}_{2}$ in leaves via a decrease in stomatal and mesophyll conductances $[65,66]$; or (2) give rise to secondary effects-oxidative stress [65]. In Farooq et al. [67], it was added that drought is also associated with accelerated leaf senescence and reduction in crop yield.

\subsubsection{Plants' Responses to Water Stress}

Akinci and Losel [68] indicated that plant adaptation to dry environments can be expressed at four different levels which are phenological or developmental, morphological, physiological, and metabolic while the latter (metabolic or biochemical adaptation) is the least understood. Whereas some responses of plants to water stress occur at the leaf level [69], it is the general response at the whole-plant level, involving carbon assimilation and the distribution of photoassimilates to different plant parts and reproductive ability that eventually determine the survival of these plants and persistence under environmental stress [69]. Nonetheless, carbon assimilation at this whole-plant level always decreases as a result of (1) reduction in $\mathrm{CO}_{2}$ diffusion into the leaf; (2) diversion of carbon distribution to non-photosynthetic organs and defence molecules; or (3) biochemical changes in the leaf leading to the down-regulation of photosynthesis [69]. The various responses of plants to water stress are summarised in Table 2. 


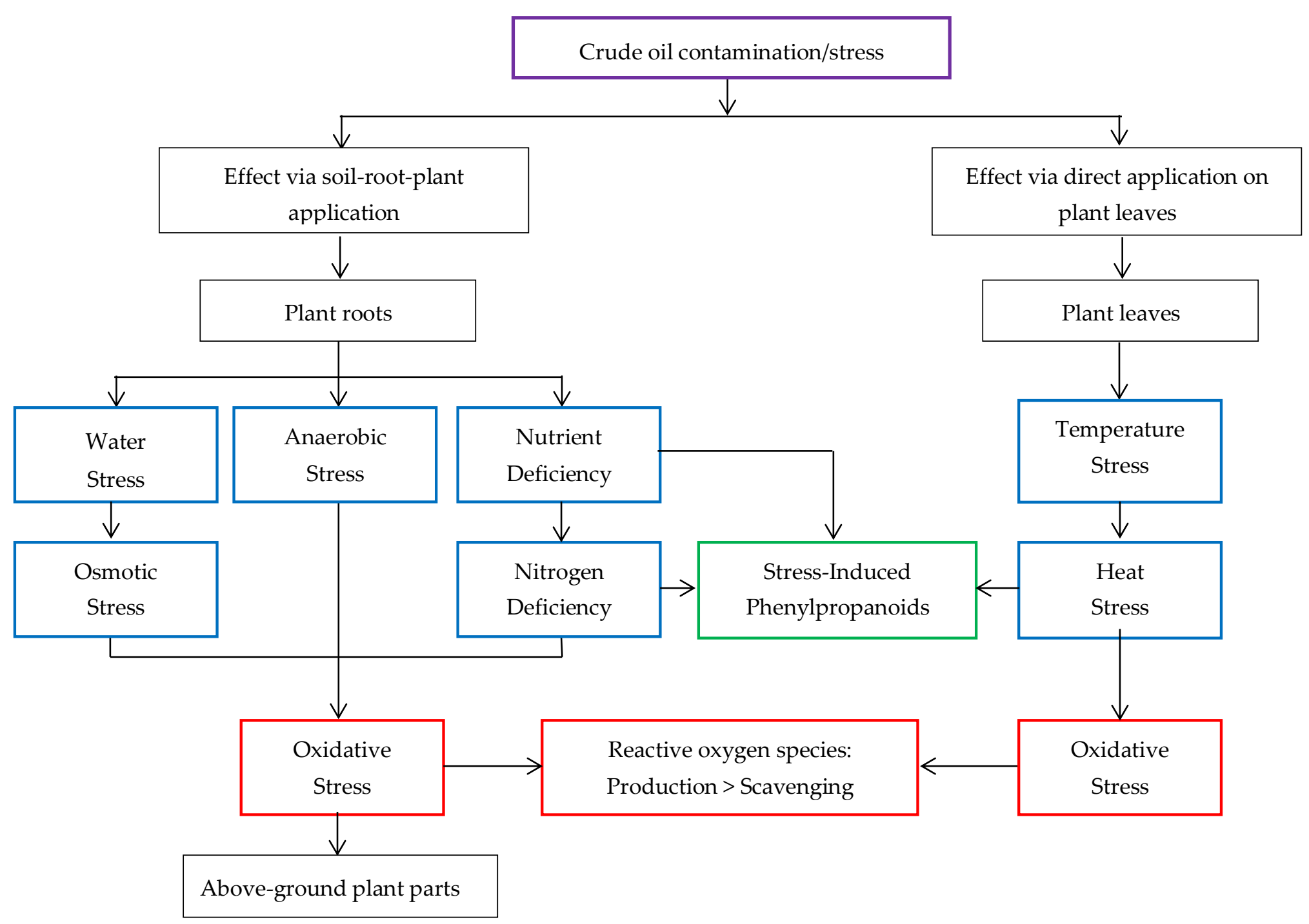

Figure 7. Illustration of the mechanistic link between crude oil contamination/stress and the crude oil-induced abiotic stresses as it affects agrifood production. 
Table 2. Summary of plants' responses to water stress.

\begin{tabular}{|c|c|c|c|}
\hline Type of Response & Impact Indicators & Parts of Plants/Processes Affected & References \\
\hline \multirow{13}{*}{$\begin{array}{c}\text { Morphological and } \\
\text { physiological responses }\end{array}$} & \multirow{2}{*}{ Crop growth and yield } & $\begin{array}{l}\text { Reduced growth parameters such as height, leaf number, leaf area index as } \\
\text { well as fresh and dry weight. }\end{array}$ & $\begin{array}{l}\text { Akinci and Losel [68] } \\
\text { Timpa et al. [70] }\end{array}$ \\
\hline & & * Shoot growth may be more inhibited than root growth. & $\begin{array}{c}\text { Sharp [71] } \\
\text { Sharp and Davies [72] }\end{array}$ \\
\hline & \multirow{2}{*}{ Water relations } & $\begin{array}{l}\text { Affects plant water relations, stomatal closure, gas exchange, transpiration, } \\
\text { and carbon assimilation (photosynthesis). }\end{array}$ & Lisar [63] \\
\hline & & * Stomatal opening and closing is more strongly influenced. & Farooq et al. [67] \\
\hline & \multirow{4}{*}{ Nutrient relations } & $\begin{array}{l}\text { Reduced ability of plant roots to absorb water and nutrients which could be } \\
\text { as a result of a decrease in nutrient element demand. }\end{array}$ & $\begin{array}{l}\text { Akinci and Losel [68] } \\
\text { Alam [73] }\end{array}$ \\
\hline & & Reduced availability, uptake, translocation and metabolism of nutrients. & Farooq et al. [67] \\
\hline & & Increase in $\mathrm{K}, \mathrm{Na}, \mathrm{Ca}, \mathrm{Mg}$, and $\mathrm{Cl}$; decrease in $\mathrm{P}$ and $\mathrm{Fe}$. & Abdel Rahman et al. [74] \\
\hline & & Increase in $\mathrm{N}$; decrease in $\mathrm{P}$; no effect on $\mathrm{K}$. & Farooq et al. [67] \\
\hline & \multirow{3}{*}{ Osmotic adjustment } & $\begin{array}{l}\text { Lowering water deficiency impact and linked to the maintenance of } \\
\text { stomatal conductance, photosynthesis, leaf water volume, and growth. }\end{array}$ & \multirow{3}{*}{ Akinci and Losel [68] } \\
\hline & & $\begin{array}{l}\text { * Most often temporary as plants usually respond quickly to increase in the } \\
\text { level of available water. }\end{array}$ & \\
\hline & & $\begin{array}{l}\text { * Solutes accumulate with water stress and contribute to osmotic adjustment } \\
\text { in non-halophytes including inorganic cations, organic acids, carbohydrates, } \\
\text { and amino acids. }\end{array}$ & \\
\hline & Photosynthesis & $\begin{array}{l}\text { Negative effect on photosynthesis of crops and possibly a cessation in the } \\
\text { photosynthetic process. }\end{array}$ & Akinci and Losel [68] \\
\hline & Assimilate partitioning & $\begin{array}{l}\text { Often enhanced allocation of dry matter to the roots increasing root growth } \\
\text { which can support greater water uptake. }\end{array}$ & Farooq et al. [67] \\
\hline
\end{tabular}


Table 2. Cont

\begin{tabular}{|c|c|c|c|}
\hline Type of Response & Impact Indicators & Parts of Plants/Processes Affected & References \\
\hline \multirow{8}{*}{$\begin{array}{l}\text { Metabolic and molecular } \\
\text { responses }\end{array}$} & \multirow[t]{2}{*}{ Carbohydrate changes } & $\begin{array}{l}\text { For moderate water stress, plant response is more regulatory rather than } \\
\text { stress-induced damage. }\end{array}$ & Chaves [64] \\
\hline & & Accumulation of sugars and other organic solutes. & Akinci and Losel [68] \\
\hline & \multirow{3}{*}{ Plant proteins } & Reduction in plant protein synthesis. & $\begin{array}{l}\text { Akinci and Losel [68] } \\
\text { Dhindsa and Cleland [75] } \\
\text { Ben-Zioni et al. [76] }\end{array}$ \\
\hline & & Levels of some specific types of proteins and mRNA may increase. & Akinci and Losel [68] \\
\hline & & $\begin{array}{l}\text { * Three kinds of osmolytes found in water stressed organisms except the } \\
\text { halobacteria include polyhydric alcohols, free amino acids, and their } \\
\text { derivatives, combinations of urea and methylamines. }\end{array}$ & Yancey et al. [77] \\
\hline & \multirow[b]{2}{*}{ Plant lipids } & Contradictory reports on the effect on plant lipids. & Akinci and Losel [68] \\
\hline & & $\begin{array}{l}\text { Hindered fatty acid desaturation which gives rise to a sharp decrease in } \\
\text { linoleic and linolenic acid biosynthesis. }\end{array}$ & $\begin{array}{l}\text { Akinci and Losel [68] } \\
\text { Pham Thi et al. [78] }\end{array}$ \\
\hline & Oxidative damage & Can lead to the production of ROS. & Teotia and Singh [79] \\
\hline
\end{tabular}

* Additional information. 


\subsubsection{Osmotic Stress}

In line with Zhu et al. [80], osmotic stress may be used to refer to conditions in which there is a limitation on plant growth and development as a result of shortage of water availability. Although osmotic stress can result from drought, excessive salt in water, chilling, and freezing [80], Xiong and Zhu [81] identified drought and high salinity as the chief causes of stress to plants under natural conditions.

Plants respond to osmotic stress at the morphological, anatomical, and cellular levels [80] which results in alterations in their development (such as the plant life cycle, limitation of shoot growth, and enhancement of root growth), regulation in ion transport as well as metabolic changes which may involve carbon metabolism and production of compatible solutes [45,81]. Some of these responses according to Xiong and Zhu [81] are triggered by the primary osmotic stress signals while others can be linked to secondary stresses/signals resulting from the primary signals. Examples of the secondary signals are phytohormones [such as abscisic acid (ABA) and ethylene], ROS as well as intracellular second messengers (e.g., phospholipids) [81].

Generally, the response of plants to osmotic stresses can be classified into three different forms involving (a) the maintenance of homeostasis; (b) detoxification of harmful elements; and (c) efforts towards growth recovery [81].

\subsection{Anaerobic Stress}

Higher plants, being aerobes, need molecular oxygen from their environment for survival [82]. However, under certain environmental conditions, there is a possibility of shortage in the supply of $\mathrm{O}_{2}$ to plant tissues [83]. When this happens, that is, when there is restricted aeration of part or all of the plant, "the resulting tissue hypoxia or anoxia inevitably suppresses oxygen-dependent pathways especially the energy-generating system, disturbs functional relationships between organs such as roots and shoots, as well as suppresses both carbon assimilation and photosynthate utilization" [82].

This shortage in the supply of oxygen has more direct effect on underground organs such as the roots and seeds; the shoot systems are then indirectly affected as a result of the negative impact of the stress on the root functions upon which the shoots depend [82]. The mitochondria have also been identified by Vartapetian et al. [84] as suffering from oxygen deficiency before other cell organelles are affected. Most plants tissues can, however, withstand anoxia (lack of oxygen) only for a short period of time before irreversible damage occurs [85].

\section{Plants' Responses to Anaerobic Stress}

Depletion of oxygen affects cell physiology; it alters gene expression, energy consumption, cellular metabolism, growth, and development [86]. Based on findings by the authors, Blokhina et al. [87] indicated that lack of oxygen primarily results in a decrease in adenylate energy charge, cytoplasmic acidification, anaerobic fermentation, increase in cytosolic $\mathrm{Ca}^{2+}$ concentration, alterations in the redox state, and a decline in the membrane barrier function. Low-oxygen (hypoxia) stress is also reported to induce significant changes in the transcriptome as well as a shift from aerobic to anaerobic respiration [88].

(a) Pasteur effect: Mustroph et al. [89] identified the Pasteur effect as a common eukaryotic response to oxygen deficiency at the cellular level. According to Winkler et al. ([90], p. 721), this definition "that the rate of fermentation rises when oxygen is excluded" for the Pasteur effect by Krebs [91] has long been accepted in place of that involving "the inhibition of glycolysis by respiration". Kennedy et al. [85] added that most anaerobic-intolerant plants exhibit a pronounced Pasteur effect.

(b) ROS production and oxidative stress: Like many other stress conditions, hypoxia is associated with the excess generation of ROS [87]. Along these lines, there are two models which suggest (1) a decrease in ROS under oxygen deprivation \{low NADPH-nicotine adenine dinucleotide 
phosphate [92]—oxidase activity\}; or (2) an increase in ROS due to inhibition of the mitochondrial electron transport chain.

(c) Gene expression: As the synthesis of several proteins involved in glycolysis and fermentation processes is induced in plants under anaerobic conditions [93], Agarwal and Grover [94] noted that plants respond to low $\mathrm{O}_{2}$-stress condition via specific alterations in gene expression. Generally, anaerobiosis gives rise to the alteration of gene expression in plants which leads to the accumulation of anaerobic proteins (ANPs) [95] many of which are metabolic pathway enzymes [94].

\subsection{Nutrient Deficiency}

Plants need nutrient elements for their normal growth and development in which the deficiency in any required element will have a significant impact [96]. Clarkson et al. [97] indicated that the level of availability of certain mineral nutrients can alter plant transpiration, stomatal conductance, and root hydraulic conductivity while the deficiency of any of these three plant nutrients-nitrate, phosphate, and sulphate-in the growth medium, would impact the stomatal conductance and root hydraulic conductivity in a similar way.

In line with Kandlbinder et al. [98], there are two contrasting developmental and metabolic effects that can be induced by nutrient deficiency. At the first instance, which shows the adaptive response, the growth of plants may decrease in an organised manner in which the number as well as size of each part of the plant (involving the roots, leaves, shoots, and regenerative organs) are reduced while the metabolic activity and 'fitness' are to a large extent unaffected [98]. In the second, the unbalanced response gives rise to a disturbed environment and dysfunction of the whole plant-the plant becomes stressed [98].

\subsubsection{Plants' Responses to Nutrient Deficiency}

(a) Biosynthesis of stress-induced phenylpropanoids: Environmental (biotic and abiotic) stresses like pathogen attack, wounding, nutrient deficiencies, and temperature, among others (Figure 8), are capable of enhancing the levels of phenylpropanoids in plants $[99,100]$.

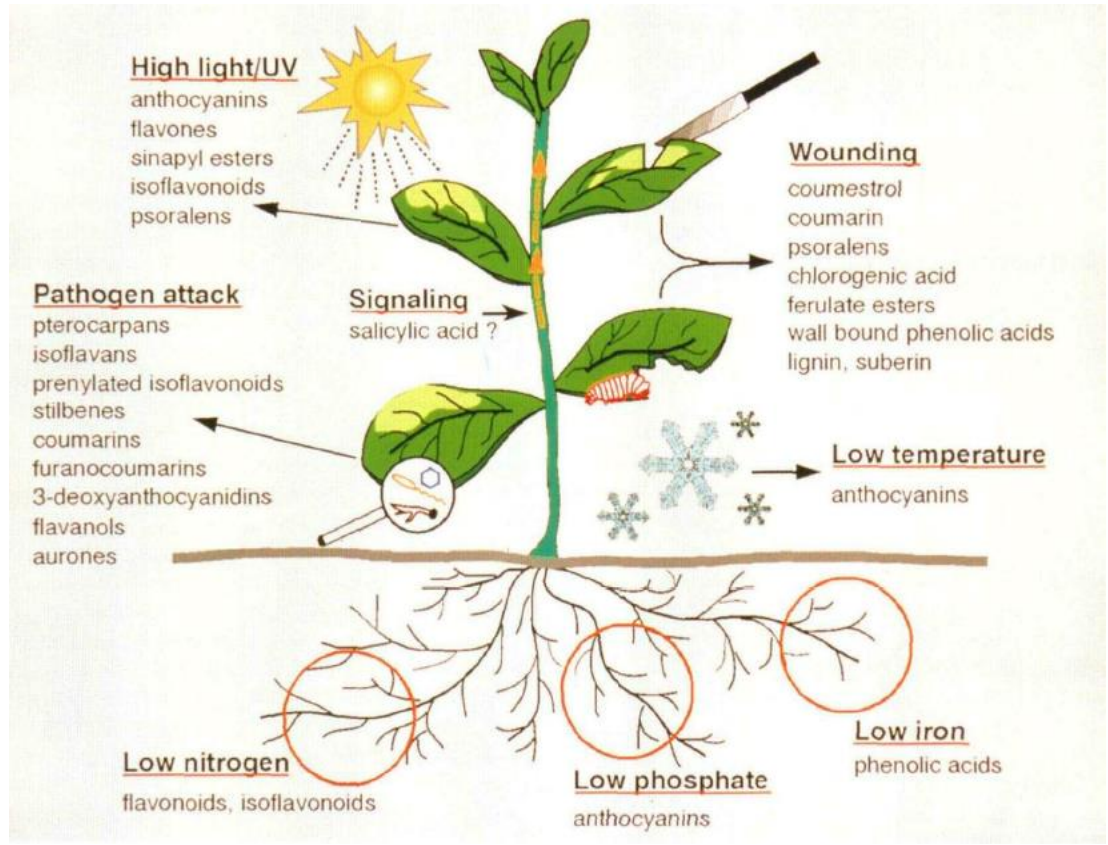

Figure 8. Examples of stress-induced phenylpropanoids. Source: Dixon and Paiva [100].

These phenylpropanoids are plant secondary metabolites $[99,101,102]$ derived from trans-cinnamic acid, produced from the deamination of L-phenylalanine via the action of the enzyme - phenylalanine 
ammonia-lyase (PAL) $[99,100]$. The other two enzymes involved in the first three steps that brings about the synthesis of these secondary metabolites (phenylpropanoid-derived compounds), which together are referred to as the general phenylpropanoid pathway (GPP) (Figure 9), are cinnamate 4-hydroxylase (C4H) and p-coumaroyl coenzyme A ligase (4CL) [101].

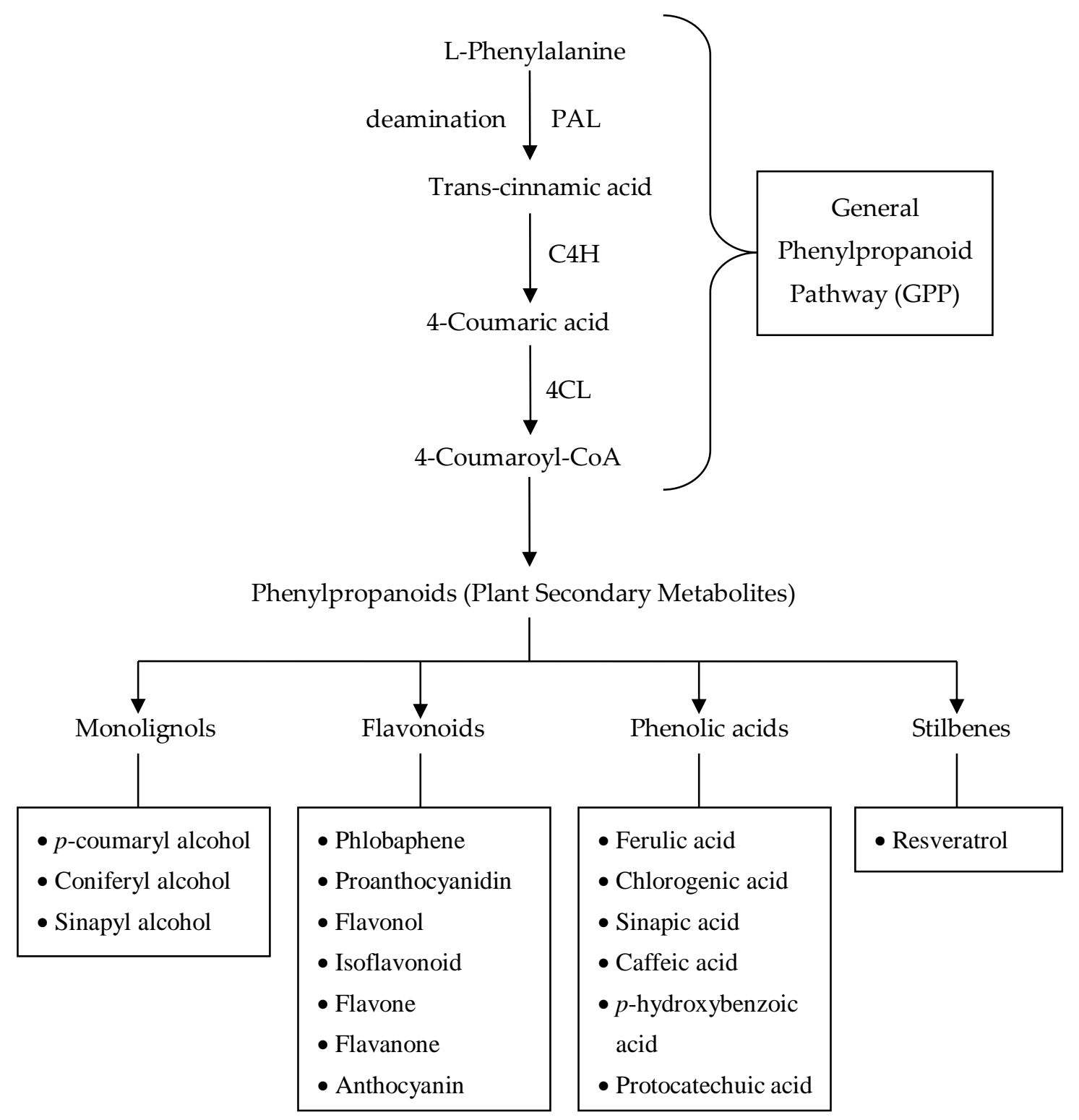

Figure 9. Biosynthesis pathway of some plant phenylpropanoid compounds ( $\mathrm{PAL}=$ phenylalanine ammonia lyase; $\mathrm{C} 4 \mathrm{H}=$ cinnamate 4 -hydroxylase; $4 \mathrm{CL}=p$-coumaroyl coenzyme A ligase). Adapted from: $[101,102]$.

In line with Lillo et al. [103], the shikimate pathway is found in plants and provides phenylalanine for the synthesis of protein and secondary metabolites (like lignin and flavonoids). This shikimate pathway, with distinct patterns of organ-specific as well as tissue-specific activity, however, depends on developmental regulation and environmental stimuli [104]. The enzymes of this pathway also respond to nitrogen and amino acid starvation [104].

On the other hand, Gershenzon [105] indicated that nitrogen, phosphorus, potassium, and sulphur deficiencies most times lead to higher concentrations of phenolic compounds. 
(b) Oxidative stress: Following the acknowledgment of the relationship between macronutrient deficiency and oxidative stress by Tewari et al. [106], Kandlbinder et al. [98] in their study found that $\mathrm{N}-, \mathrm{P}_{-}$, and S-nutrient deprivation triggered redox changes and induced oxidative stress.

\subsubsection{Nitrogen Deficiency/Stress}

Aside from oxygen, carbon, and hydrogen, among other mineral nutrients, plants need greater amounts of nitrogen [107] whose deficiency Kovacik et al. [108] regarded as an abiotic stress factor based on the experimental results of Shin et al. [109] in which $\mathrm{H}_{2} \mathrm{O}_{2}$ production occurred in nitrogen-deprived roots. Kovacik et al. [110] also considered its absence as a form of abiotic stress.

Nitrogen deficiency is associated with increased phenolic concentration $[105,108,111]$ including flavonoids [108,112,113] and coumarins [108,110]. It is, however, linked with reduced mass-based protein content [114]. In the view of Bongue-Bartelsman and Phillips [112], the increased deamination of phenylalanine could be responsible for elevated flavonoid content under nitrogen limitation.

In addition, Kovacik et al. [110] indicated that nitrogen deficiency will affect amino acids and carbon metabolism while Kovacik et al. [108] as well as Shin et al. [109] added that nitrogen limitation can encourage the generation of ROS. When the level of these ROS produced exceeds that of removal by the antioxidant defense mechanisms, oxidative stress occurs in the cell [115].

The indicators of senescence, which is an important outcome of $\mathrm{N}$ or P deficiency [106], is reported to be similar to those of oxidative stress which include net loss of chloroplastic pigments and proteins [106,116-118], lipid peroxidation, and membrane alterations, giving rise to a progressive decline in photosynthetic capacity $[106,118]$.

\subsection{Temperature (Heat) Stress}

Although living organisms recognise temperature beyond the normal optimal as heat stress [119], Wahid et al. [120] referred the transient increase in temperature, usually $10-15^{\circ} \mathrm{C}$ above ambient, as heat shock or heat stress. They also added that heat stress occurs when there is an increase in temperature above a threshold level for a period of time which can cause irreversible damage to plant growth as well as development. In other words, heat stress depends on the intensity (in terms of temperature in degrees), time of exposure, and rate of increase in temperature. For instance, very high temperatures may lead to severe cellular injury and cell death within minutes as a result of the damaging effect on cellular organization. However, at moderately high temperature, injuries, or death may still occur but after a long-term exposure [120].

\section{Plants' Responses to Temperature (Heat) Stress}

The direct adverse effects of high temperature include protein denaturation and aggregation, as well as increased fluidity of membrane lipids. Meanwhile, enzyme inactivation in chloroplast and mitochondria, inhibition of protein synthesis, protein degradation, and loss of membrane integrity are associated with indirect or slower heat injuries. The resultant effects of these injuries are starvation, growth inhibition, reduced ion flux as well as production of toxic compounds and ROS (Wahid et al. [120]). The established responses of plants to temperature/heat stress are highlighted in Table 3. 
Table 3. Summary of plants' responses to temperature/heat stress.

\begin{tabular}{|c|c|c|c|}
\hline Type of Response & Impact Indicators & Parts of Plants/Processes Affected & References \\
\hline \multirow{5}{*}{$\begin{array}{l}\text { Morpho-anatomical and } \\
\text { phenological responses }\end{array}$} & \multirow{2}{*}{ Morphological symptoms } & High temperature leads to loss in yield. & $\begin{array}{l}\text { Wahid et al. [120] } \\
\text { Hasanuzzaman et al. [121] } \\
\text { Guilioni et al. [122] }\end{array}$ \\
\hline & & $\begin{array}{l}\text { High temperatures affect performance and crop quality } \\
\text { characteristics. }\end{array}$ & Hasanuzzaman et al. [121] \\
\hline & Anatomical changes & $\begin{array}{l}\text { High temperature impacts anatomical structures at the tissue, } \\
\text { cellular and sub-cellular levels in which the associated alterations } \\
\text { may give rise to poor plant growth and productivity. }\end{array}$ & Wahid et al. [120] \\
\hline & \multirow{2}{*}{ Phenological changes } & $\begin{array}{l}\text { Heat stress to some extent affects all plant vegetative and } \\
\text { reproductive stages. }\end{array}$ & Wahid et al. [120] \\
\hline & & $\begin{array}{l}\text { * The extent of possible damage depends on the developmental stage } \\
\text { of the plant. }\end{array}$ & Wollenweber et al. [123] \\
\hline \multirow{6}{*}{ Physiological responses } & \multirow{2}{*}{ Water relations } & $\begin{array}{l}\text { When water is limiting, plant tissue water status is affected at high } \\
\text { temperature. }\end{array}$ & Wahid et al. [120] \\
\hline & & $\begin{array}{l}\text { Under field conditions, high temperature stress reduces water } \\
\text { availability which negatively affects plant productivity. }\end{array}$ & Simoes-Araujo et al. [124] \\
\hline & $\begin{array}{l}\text { Accumulation of compatible } \\
\text { osmolytes }\end{array}$ & This is a basic adaptive mechanism. & $\begin{array}{l}\text { Wahid et al. [120] } \\
\text { Bohnert et al. [125] } \\
\text { Hare et al. [126] } \\
\text { Sakamoto and Murata [127] }\end{array}$ \\
\hline & \multirow{3}{*}{ Photosynthesis } & $\begin{array}{l}\text { At moderate heat stress, inhibition of photosynthesis is reversible. } \\
\text { Severe heat stress causes permanent damage to the photosynthetic } \\
\text { apparatus. }\end{array}$ & Salvucci and Crafts-Brandner [128] \\
\hline & & $\begin{array}{l}\text { Has more significant effect on the photosynthetic capacity of } C_{3} \\
\text { plants than that of } C_{4} \text { plants. }\end{array}$ & Wahid et al. [120] \\
\hline & & $\begin{array}{l}\text { * Regarded as the physiological process most susceptible to high } \\
\text { temperatures. }\end{array}$ & Wahid et al. [120] \\
\hline
\end{tabular}


Table 3. Cont

\begin{tabular}{|c|c|c|c|}
\hline Type of Response & Impact Indicators & Parts of Plants/Processes Affected & References \\
\hline \multirow{6}{*}{ Physiological responses } & Assimilate partitioning & $\begin{array}{l}\text { Low to moderate heat stress may cause a reduction in source and } \\
\text { sink activities giving rise to severe reductions in plant growth, } \\
\text { economic yield, and harvest index. } \\
\text { High temperatures affect the transport and transfer processes in } \\
\text { plants because of assimilate partitioning taking place via apoplastic } \\
\text { and symplastic pathways. }\end{array}$ & Wahid et al. [120] \\
\hline & \multirow[t]{2}{*}{$\begin{array}{l}\text { Cell membrane } \\
\text { thermostability }\end{array}$} & $\begin{array}{l}\text { Increases the kinetic energy and movement of molecules across } \\
\text { membranes resulting in loosening of the chemical bonds within } \\
\text { molecules in biological membranes. }\end{array}$ & \multirow[t]{2}{*}{ Wahid et al. [120] } \\
\hline & & Affects the tertiary and quaternary structures of membrane proteins. & \\
\hline & \multirow{2}{*}{ Hormonal changes } & $\begin{array}{l}\text { Affects hormonal homeostasis, stability, content, biosynthesis, and } \\
\text { compartmentalization. }\end{array}$ & \multirow[t]{2}{*}{ Wahid et al. [120] } \\
\hline & & $\begin{array}{l}\text { Gives rise to increased levels of abscisic acid (ABA) which brings } \\
\text { about modification of gene expression in response to stress. }\end{array}$ & \\
\hline & Secondary metabolites & $\begin{array}{l}\text { Induces production of phenolic compounds such as flavonoids and } \\
\text { phenylpropanoids. }\end{array}$ & Wahid et al. [120] \\
\hline \multirow{2}{*}{ Molecular responses } & Oxidative stress & Increases production of ROS. & Hasanuzzaman et al. $[129,130]$ \\
\hline & Stress proteins & Leads to the expression of stress proteins as an adaptive mechanism. & Wahid et al. [120] \\
\hline
\end{tabular}




\subsection{Oxidative Stress}

Oxidative stress is defined as a "state in which oxidation exceeds the antioxidant systems in the body secondary to a loss of balance between them" ([131], p. 271) and according to Lushchak ([132], p. 176) "its development is either the reason, or common event of many pathological states, including aging". In line with Lushchak [132], oxidative stress occurs in situations where the equilibrium between ROS generation and elimination is upset leading to their enhanced steady-state level. Birben et al. [92] referred it to a shift in balance between oxidant/antioxidant which favours the oxidants as shown in Figure 10. This perturbation of the equilibrium between generation and scavenging of ROS may be caused by various biotic and abiotic stress factors which are known to reduce global crop production [133].

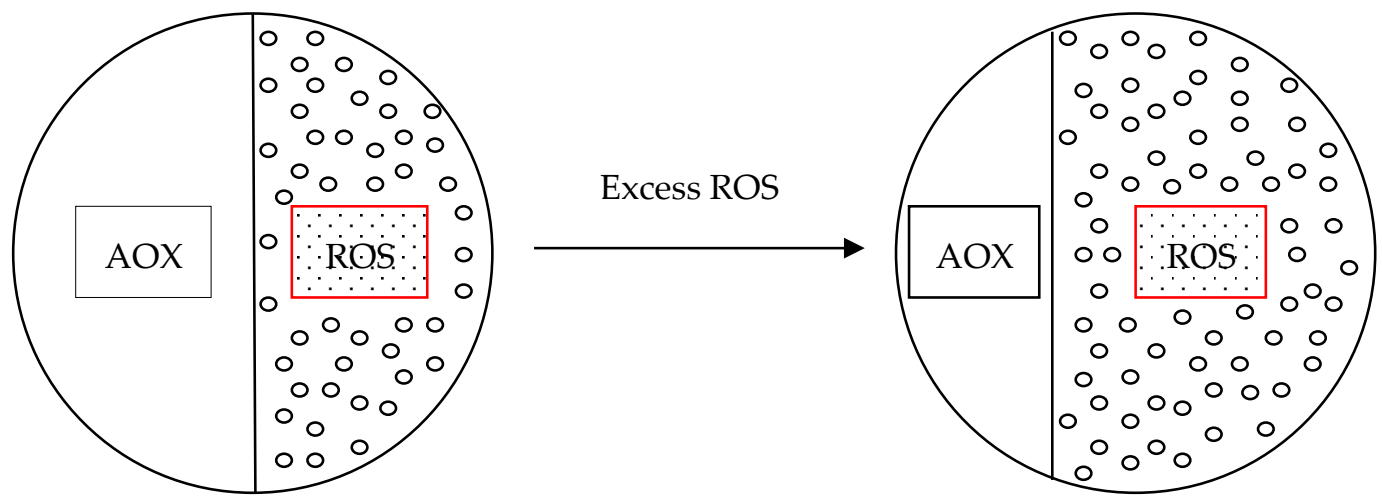

Equilibrium

$(\mathrm{AOX}=\mathrm{ROS})$
Oxidative Stress

$(\mathrm{AOX}<\mathrm{ROS})$

Figure 10. Relationship between oxidants (ROS) and antioxidants (AOX) leading to oxidative stress.

The ROS consists of free radicals, reactive molecules, as well as ions that are derived from $\mathrm{O}_{2}$, which in plants, depending on their concentrations, can either be harmful or beneficial [115]. The most common ROS are singlet oxygen $\left({ }^{1} \mathrm{O}_{2}\right)$, superoxide anion $\left(\mathrm{O}_{2}{ }^{\bullet-}\right)$, hydrogen peroxide $\left(\mathrm{H}_{2} \mathrm{O}_{2}\right)$, and hydroxyl radical $\left(\mathrm{OH}^{\bullet}\right)$ [115]. At elevated concentrations, ROS bring about damage to biomolecules while at low/moderate concentration, they function as second messengers in intracellular signaling cascades that mediate several responses in plant cells [115] such as stomatal closure [115,134,135], programmed cell death $[115,136,137]$, gravitropism $[115,138]$, and acquisition of tolerance to both biotic and abiotic stresses [115]. Mittler [139] added that ROS levels that are too low (cytostatic level) or too high (cytotoxic level) have a negative effect on plant growth and development while ROS level within the right range (basal level) support plant health.

As noted by Sharma et al. [115], in plants, ROS are generated in both unstressed and stressed cells at different locations in chloroplasts, mitochondria, plasma membranes, peroxisomes, apoplast, endoplasmic reticulum, and cell walls. These authors added that the ROS are usually produced as a result of the leakage of electrons onto $\mathrm{O}_{2}$ from the electron transport activities of chloroplasts, mitochondria, and plasma membranes or as byproducts of various metabolic pathways in different cellular compartments.

Generally, under ideal growth conditions, the generation of ROS in organelles is low [140] but are formed excessively during adverse/stressful conditions [140,141], which can bring about damage to biomolecules like lipids, proteins, and deoxyribonucleic acid (DNA) [115]. These reactions according to Sharma et al. [115] can affect intrinsic membrane properties such as fluidity, ion transport, loss of enzyme activity, protein cross-linking, inhibition of protein synthesis, and DNA damage, which 
eventually lead to cell death. Gill and Tuteja [142] pointed out that in addition to the ability of ROS to damage cells, they can also initiate responses such as new gene expression.

Plants' Responses to ROS and Oxidative Stress (Antioxidant Systems)

In line with Gill and Tuteja [142], the balance between generation of ROS and scavenging at the proper site as well as time, determines whether ROS will act as damaging, protective or signaling factors. Hence, as a result of the multifunctional roles of these ROS, cells must control their levels to prevent any oxidative injury but not eliminate them completely [115]. The scavenging or detoxification of excess ROS is carried out by the antioxidant system comprising the non-enzymatic antioxidants and enzymatic antioxidants [115]. The former class of non-enzymatic antioxidants within cells is comprised of ascorbic acid (AA), glutathione (GSH), carotenoids, $\alpha$-tocopherol, phenolics and amino acids like proline while the latter class (enzymatic antioxidants) include superoxide dismutase (SOD), catalase (CAT), ascorbate peroxidase (APX), monodehydroascorbate reductase (MDHAR), dehydroascorbate reductase (DHAR), glutathione reductase (GR), and guaiacol peroxidase (GPX) [115,143].

Basically, the ability of plants to maintain a high antioxidant capacity to scavenge toxic ROS (i.e., reduce oxidative stress) implies increased plant tolerance level to environmental stresses [115,144]. Figure 11 provides a connection between the impact of the various levels of ROS on plants and the antioxidant system. 


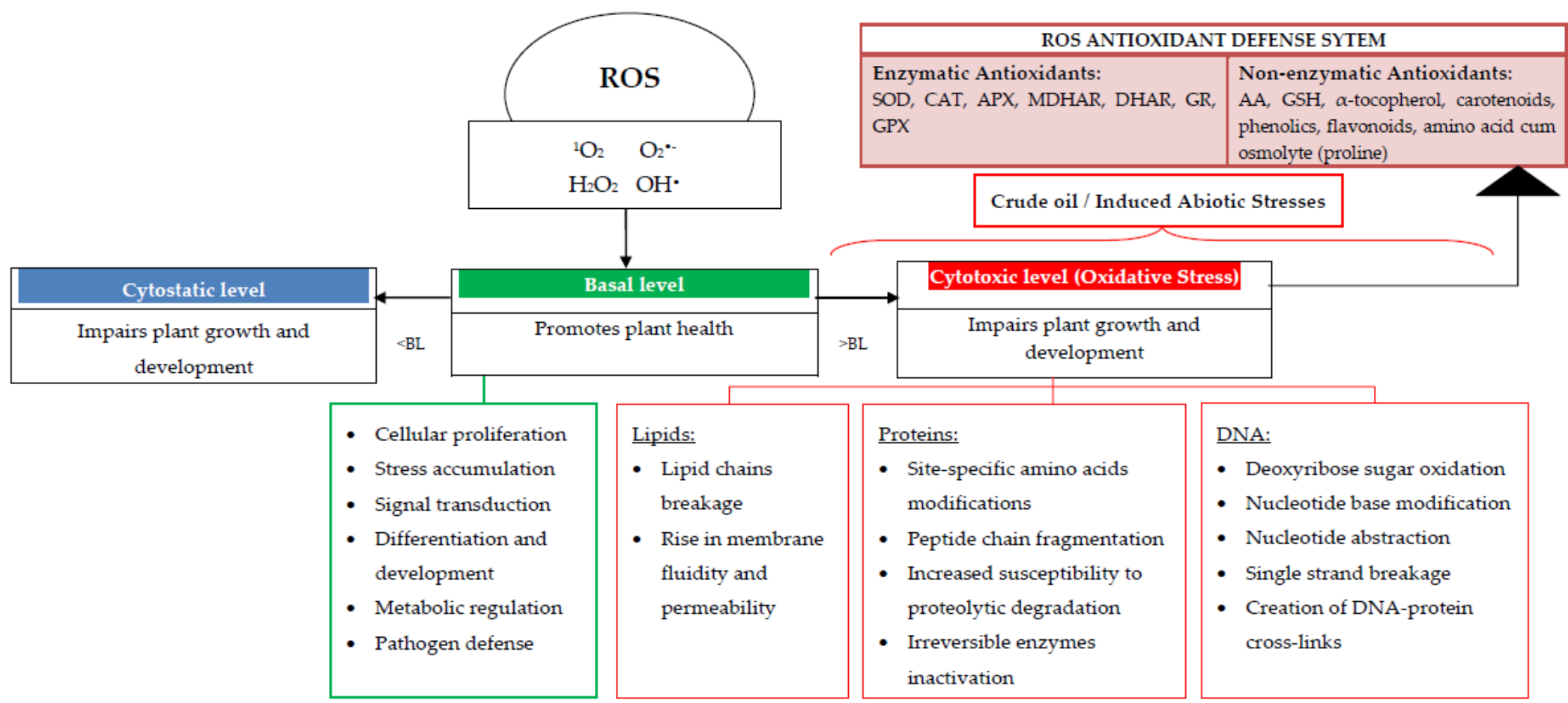

Figure 11. Connection between the impact of the various levels of ROS on plants and the antioxidant system. ROS = reactive oxygen species; BL = basal level; $\mathrm{DNA}=$ deoxyribonucleic acid $\mathrm{SOD}=$ superoxide dismutase, $\mathrm{CAT}=$ catalase, $\mathrm{APX}=$ ascorbate peroxidase, $\mathrm{MDHAR}=$ monodehydroascorbate reductase, $\mathrm{DHAR}=$ dehydroascorbate reductase, GR = glutathione reductase, GPX = guaiacol peroxidase; AA = ascorbic acid, GSH = glutathione. Adapted from: Reference [115,139,142]. 


\section{Conclusions}

Although a number of studies have recorded the negative impacts of crude oil contamination at toxic levels on plants, this review elucidates the underlying factors responsible for the observed responses in the crude oil-stressed plants. It highlights the various ways in which crude oil and its induced abiotic stresses may affect the composition of agricultural produce. It is believed that a clear understanding on the influence of crude oil contamination/induced abiotic stresses on crop yield, quality, and agrifood production, in general, would assist the government, agronomists, environmental as well as food scientists in proffering solutions to the problem of food security in regions of the world prone to/affected by crude oil spills.

Author Contributions: J.O., R.L., and R.S. provided the concept. J.O. and R.S. wrote, reviewed and edited the manuscript.

Funding: This research was funded by the Petroleum Technology Development Fund (PTDF), Nigeria, PhD scholarship award grant number PTDF/E/OSS/PHD/OJO/625/12.

Conflicts of Interest: The authors declare no conflict of interest.

\section{References}

1. Athar, H.; Ambreen, S.; Javed, M.; Hina, M.; Rasul, S.; Zafar, Z.U.; Manzoor, H.; Ogbaga, C.C.; Afzal, M.; Al-Qurainy, F.; et al. Influence of sub-lethal crude oil concentration on growth, water relations and photosynthetic capacity of maize (Zea mays L.) plants. Environ. Sci. Pollut. Res. 2015, 23, 18320-18331. [CrossRef] [PubMed]

2. Khamehchiyan, M.; Hossein Charkhabi, A.; Tajik, M. Effects of crude oil contamination on geotechnical properties of clayey and sandy soils. Eng. Geol. 2007, 89, 220-229. [CrossRef]

3. Ajagbe, W.O.; Omokehinde, O.S.; Alade, G.A.; Agbede, O.A. Effect of crude oil impacted sand on compressive strength of concrete. Constr. Build. Mater. 2012, 26, 9-12. [CrossRef]

4. Ivshina, I.B.; Kuyukina, M.S.; Krivoruchko, A.V.; Elkin, A.A.; Makarov, S.O.; Cunningham, C.J.; Peshkur, T.A.; Atlas, R.M.; Philp, J.C. Oil spill problems and sustainable response strategies through new technologies. Environ. Sci. Process. Impacts 2015, 17, 1201-1219. [CrossRef] [PubMed]

5. Odukoya, J.O. Influence of Bioremediation on the Chemical and Nutritional Composition of Produce from Crude Oil-Polluted Sites. Ph.D. Thesis, Cranfield University, Cranfield, UK, 2016.

6. Ndimele, P.E.; Saba, A.O.; Ojo, D.O.; Ndimele, C.C.; Anetekhai, M.A.; Erondu, E.S. Remediation of crude oil spillage. In The Political Ecology of Oil and Gas Activities in the Nigerian Aquatic Ecosystem; Ndimele, P.E., Ed.; Academic Press: London, UK, 2018; pp. 369-384.

7. Schmidt-Etkin. Spill occurences: A world overview. In Oil Spill science and Technology: Prevention, Response, and Cleanup, 1st ed.; Fingas, M., Ed.; Gulf Professional Publishing: Amsterdam, The Netherlands, 2011.

8. Yavari, S.; Malakahamad, A.; Sapari, N.B. A review on phytoremediation of crude oil spills. Water Air Soil Pollut. 2015, 226, 226. [CrossRef]

9. Levy, J.K.; Gopalakrishnan, C. Promoting ecological sustainability and community resilience in the US Gulf Coast after the 2010 Deepwater Horizon oil spill. J. Nat. Resour. Policy Res. 2010, 2, 297-315. [CrossRef]

10. Okpokwasili, G.; Odokuma, L. Effect of salinity on biodegradation of oil spill dispersants. Waste Manag. 1990, 10, 141-146. [CrossRef]

11. Njoku, K.L.; Akinola, M.O.; Oboh, B.O. Phytoremediation of crude oil contaminated soil: The effect of growth of Glycine max on the physico-chemistry and crude oil contents of soil. Nat. Sci. 2009, 7, 22-30.

12. Ylitalo, G.M.; Krahn, M.M.; Dickhoff, W.W.; Stein, J.E.; Walker, C.C.; Lassitter, C.L.; Garrett, E.S.; Desfosse, L.L.; Mitchell, K.M.; Noble, B.T.; et al. Federal seafood safety response to the Deepwater Horizon oil spill. Proc. Natl. Acad. Sci. USA 2012, 109, 20274-20279. [CrossRef]

13. Venosa, A.D.; Suidan, M.T.; Wrenn, B.A.; Strohmeier, K.L.; Haines, J.R.; Eberhart, B.L.; King, D.; Holder, E. Bioremediation of an experimental oil spill on the shoreline of Delaware Bay. Environ. Sci. Technol. 1996, 30, 1764-1775. [CrossRef]

14. Ebuehi, O.; Abibo, I.; Shekwolo, P.; Sigismund, K.; Adoki, A.; Okoro, I. Remediation of crude oil contaminated soil by enhanced natural attenuation technique. J. Appl. Sci. Environ. Manag. 2005, 9, 103-106. 
15. Couto, M.N.P.F.S.; Monteiro, E.; Vasconcelos, M.T.S.D. Mesocosm trials of bioremediation of contaminated soil of a petroleum refinery: Comparison of natural attenuation, biostimulation and bioaugmentation. Environ. Sci. Pollut. Res. 2010, 17, 1339-1346. [CrossRef] [PubMed]

16. Adekunle, I.M. Bioremediation of soils contaminated with Nigerian petroleum products using composted municipal wastes. Bioremediat. J. 2011, 15, 230-241. [CrossRef]

17. Kuhn, W.; Gambino, R.; Al-Awadhi, N.; Balba, M.T.; Dragun, J. Growth of tomato plants in soil contaminated with Kuwait crude oil. J. Soil Contam. 1998, 7, 801-806. [CrossRef]

18. Adam, G.; Duncan, H. Influence of diesel fuel on seed germination. Environ. Pollut. 2002, 120, 363-370. [CrossRef]

19. Adieze, I.E.; Orji, J.C.; Nwabueze, R.N.; Onyeze, G.O.C. Hydrocarbon stress response of four tropical plants in weathered crude oil contaminated soil in microcosms. Int. J. Environ. Stud. 2012, 69, 490-500. [CrossRef]

20. Inckot, R.C.; Santos, G.D.O.; de Souza, L.A.; Bona, C. Germination and development of Mimosa pilulifera in petroleum-contaminated soil and bioremediated soil. Flora 2011, 206, 261-266. [CrossRef]

21. Baruah, P.; Saikia, R.R.; Baruah, P.P.; Deka, S. Effect of crude oil contamination on the chlorophyll content and morpho-anatomy of Cyperus brevifolius (Rottb.) Hassk. Environ. Sci. Pollut. Res. 2014, 21, 12530-12538. [CrossRef]

22. Odukoya, J.; Lambert, R.; Sakrabani, R. Influence of sub-lethal concentrations of crude oil on tomato yield and quality. SAJFTE 2018, 4, 722-733.

23. Odukoya, J.; Lambert, R.; Sakrabani, R. Impact of crude oil on yield and phytochemical composition of selected green leafy vegetables. Int. J. Veg. Sci. 2019. [CrossRef]

24. Chupakhina, G.N.; Maslennikov, P.V. Plant adaptation to oil stress. Russ. J. Ecol. 2004, 35, 290-295. [CrossRef]

25. Noori, A.S.; Maivan, H.Z.; Alaie, E. Changes in total phenol and flavonoid contents in Chrysanthemum leucanthemum under crude oil contamination. Adv. Environ. Biol. 2012, 6, 3057-3064.

26. Coulon, F.; Wu, G. Determination of Petroleum Hydrocarbon Compounds from Soils and Sediments Using Ultrasonic Extraction. In Hydrocarbon and Lipid Microbiology Protocols: Petroleum, Hydrocarbon and Lipid Analysis; McGenity, T.J., Timmis, K.N., Nogales, B., Eds.; Springer Protocols Handbooks: Berlin, Heidelberg, 2014; pp. 31-46.

27. United Nations Environment Programme, UNEP. Environmental Assessment of Ogoniland; 978-92-807-3130-9; United Nations Environment Programme: Nairobi, Kenya, 2011.

28. Oghenejoboh, K.M.; Puyate, Y.T.; Abowei, M.F.N. Concentration distribution of spilled crude petroleum in different soils 2: Effects of volume of oil on spatial spread. Pollut. Res. 2008, 27, 605-610.

29. Pezeshki, S.R.; DeLaune, R.D. United States Gulf of Mexico coastal marsh vegetation response and sensitivities to oil spill: A review. Environments 2015, 2, 586-607. [CrossRef]

30. Plice, M.J. Some effects of crude petroleum on soil fertility. Soil Sci. Soc. Proc. 1948, 413-416. [CrossRef]

31. De Jong, E. The effect of a crude oil spill on cereals. Environ. Pollut. 1980, 22, 187-196. [CrossRef]

32. Merkl, N.; Schultze-Kraft, R.; Infante, C. Phytoremediation in the tropics-the effect of crude oil on the growth of tropical plants. Bioremediat. J. 2004, 8, 177-184. [CrossRef]

33. Hershner, C.; Lake, J. Effects of chronic oil pollution on salt-marsh grass community. Mar. Biol. 1980, 56, 163-173. [CrossRef]

34. Ferrell, R.E.; Seneca, E.D.; Linthurst, R.A. The effects of crude oil on the growth of Spartina alterniflora Liosel. and Spartina cynosuroides (L.) Roth. J. Exp. Mar. Biol. Ecol. 1984, 83, 27-39. [CrossRef]

35. Alexander, S.K.; Webb, J.W. Relationship of Spartina alterniflora growth to sediment oil content following an oil spill. In 1987 Oil Spill Conference Proceedings; American Petroleum Institute: Washington, DC, USA, 1987; Volume 1, pp. 445-449.

36. Lin, Q.; Mendelssohn, I.A. A comparative investigation of the effects of South Louisiana crude oil on the vegetation of fresh, brackish and salt marshes. Mar. Pollut. Bull. 1996, 32, 202-209. [CrossRef]

37. Lin, Q.; Mendelssohn, I.A. The combined effects of phytoremediation and biostimulation in enhancing habitat restoration and oil degradation of petroleum contaminated wetlands. Ecol. Eng. 1998, 10, 263-274. [CrossRef]

38. Baker, J. The effects of oils on plants. Environ. Pollut. 1970, 1, 27-44. [CrossRef]

39. Baek, K.; Kim, H.; Oh, H.; Yoon, B.; Kim, J.; Lee, I. Effects of crude oil, oil components, and bioremediation on plant growth. J. Environ. Sci. Health A 2004, 39, 2465-2472. [CrossRef] 
40. Pezeshki, S.R.; Hester, M.W.; Lin, Q.; Nyman, J.A. The effects of oil spill and clean-up on dominant US Gulf coast marsh macrophytes: A review. Environ. Pollut. 2000, 108, 129-139. [CrossRef]

41. Alexander, S.K.; Webb, J.W. Seasonal response of Spartina alterniflora to oil. In 1985 Oil Spill Conference Proceedings; American Petroleum Institute: Washington, DC, USA, 1985; Volume 1, pp. 355-357.

42. Carr, R. Vegetative growth in soils containing crude petroleum. Soil Sci. 1919, 8, 67-68. [CrossRef]

43. Rebetzke, G.; Read, J.; Barbour, M.; Condon, A.; Rawson, H. A hand-held porometer for rapid assessment of leaf conductance in wheat. Crop Sci. 2000, 40, 277-280. [CrossRef]

44. Collier, R.J.; Renquist, B.J.; Xiao, Y. A 100-year review: Stress physiology including heat stress. J. Dairy Sci. 2017, 100, 10367-10389. [CrossRef]

45. Kumar, S.P.; Minhas, P.S.; Govindasamy, V.; Choudhary, R.L. Influence of moisture stress on growth, development, physiological process and quality of fruits and vegetables and its management strategies. In Approaches to Plant Stress and Their Management; Gaur, R.K., Sharma, P., Eds.; Springer: New Delhi, India, 2014; pp. 125-148.

46. Cramer, G.R.; Urano, K.; Delrot, S.; Pezzotti, M.; Shinozaki, K. Effects of abiotic stress on plants: A systems biology perspective. BioMed. Cent. Plant Biol. 2011, 11,1-4. [CrossRef]

47. Wang, Y.; Frei, M. Stressed food-the impact of abiotic environmental stresses on crop quality. Agric. Ecosyst. Environ. 2011, 141, 271-286. [CrossRef]

48. Skirycz, A.; Inzé, D. More from less: Plant growth under limited water. Curr. Opin. Biotech. 2010, 21, $197-203$. [CrossRef]

49. Gaur, R.K.; Sharma, P. Approaches to Plant Stress and Their Management; Springer: New Delhi, India, 2014.

50. Chen, T.H.; Murata, N. Enhancement of tolerance of abiotic stress by metabolic engineering of betaines and other compatible solutes. Curr. Opin. Plant Biol. 2002, 5, 250-257. [CrossRef]

51. Bartels, D.; Sunkar, R. Drought and salt tolerance in plants. Crit. Rev. Plant Sci. 2005, 24, 23-58. [CrossRef]

52. Seki, M.; Umezawa, T.; Urano, K.; Shinozaki, K. Regulatory metabolic networks in drought stress responses. Curr. Opin. Plant Biol. 2007, 10, 296-302. [CrossRef] [PubMed]

53. Sairam, R.; Tyagi, A. Physiology and molecular biology of salinity stress tolerance in plants. Curr. Sci. India 2004, 86, 407-421.

54. Pezeshki, S.R.; DeLaune, R.D.; Nyman, J.A.; Lessard, R.R.; Canevari, G.P. Removing oil and saving oiled marsh grass using a shoreline cleaner. In 1995 International Oil Spill Conference Proceedings; American Petroleum Institute: Washington, DC, USA, 1995; pp. 203-209.

55. Noori, A.; Maivan, H.Z.; Alaie, E.; Newman, L.A. Leucanthemum vulgare Lam. crude oil phytoremediation. Int. J. Phytoremed. 2015, 20, 1292-1299. [CrossRef] [PubMed]

56. Ogbo, E.M.; Zibigha, M.; Odogu, G. The effect of crude oil on growth of the weed (Paspalum scrobiculatum L.)-phytoremediation potential of the plant. Afr. J. Environ. Sci. Technol. 2009, 3, 229-233.

57. Noori, A.S.; Maivan, H.Z.; Alaie, E. Leucanthemum vulgare Lam. germination, growth and mycorrhizal symbiosis under crude oil contamination. Int. J. Phytoremed. 2014, 16, 962-970. [CrossRef] [PubMed]

58. Sun, F.; Zhou, Q. Oxidative stress biomarkers of the polychaete Nereis diversicolor exposed to cadmium and petroleum hydrocarbons. Ecotox. Environ. Saf. 2008, 70, 106-114. [CrossRef]

59. Prendeville, G.N.; Warren, G.F. Effect of four herbicides and two oils on leaf-cell membrane permeability. Weed Res. 1977, 30, 251-258. [CrossRef]

60. Stebbings, R.E. Recovery of salt marsh in Britanny sixteen months after heavy pollution by oil. Environ. Pollut. 1970, 1, 163-167. [CrossRef]

61. Nie, M.; Xian, N.; Fu, X.; Chen, X.; Li, B. The interactive effects of petroleum-hydrocarbon spillage and plant rhizosphere on concentrations and distribution of heavy metals in sediments in the Yellow River Delta, China. J. Hazard. Mater. 2010, 174, 156-161. [CrossRef] [PubMed]

62. Wilkinson, S.; Davies, W.J. Drought, ozone, ABA and ethylene: New insights from cell to plant to community. Plant Cell Environ. 2010, 33, 510-525. [CrossRef] [PubMed]

63. Lisar, S.Y.S.; Motafakkerazad, R.; Hossain, M.M.; Rahman, I.M.M. Water stress in plants: Causes, effects and responses. In Water Stress; Rahman, I.M., Hasegawa, H., Eds.; InTech: Rijeka, Croatia, 2012.

64. Chaves, M.M. Effects of water deficits on carbon assimilation. J. Exp. Bot. 1991, 42, 1-16. [CrossRef]

65. Chaves, M.M.; Flexas, J.; Pinheiro, C. Photosynthesis under drought and salt stress: Regulation mechanisms from whole plant to cell. Ann. Bot-Lond. 2009, 103, 551-560. [CrossRef] [PubMed] 
66. Flexas, J.; Bota, J.; Loreto, F.; Cornic, G.; Sharkey, T.D. Diffusive and metabolic limitations to photosynthesis under drought and salinity in C3 plants. Plant Biol. 2004, 6, 269-279. [CrossRef]

67. Farooq, M.; Wahid, A.; Kobayashi, N.; Fujita, D.; Basra, S.M.A. Plant drought stress: Effects, mechanisms and management. Agron. Sustain. Dev. 2009, 29, 185-212. [CrossRef]

68. Akinci, S.; Losel, D.M. Plant water-stress response mechanisms. In Water Stress; Rahman, I.M., Hasegawa, H., Eds.; InTech: Rijeka, Croatia, 2012.

69. Chaves, M.M.; Pereira, J.S.; Maroco, J.; Rodrigues, M.L.; Ricardo, C.P.P.; Osorio, M.L.; Carvalho, I.; Faria, T.; Pinheiro, C. How plants cope with water stress in the field. Photosynthesis and growth. Ann. Bot-Lond. 2002, 89, 907-916. [CrossRef]

70. Timpa, J.D.; Burke, J.J.; Quisenberry, J.E.; Wendt, C.W. Effect of water stress on the organic acid and carbohydrate compositions of cotton plants. Plant Physiol. 1986, 82, 724-728. [CrossRef]

71. Sharp, R.E. Interaction with ethylene: Changing views on the role of abscisic acid in root and shoot growth responses to water stress. Plant Cell Environ. 2002, 25, 211-222. [CrossRef]

72. Sharp, R.E.; Davies, W.J. Regulation of growth and development of plants growing with a restricted supply of water. In Plants under Stress; Jones, H.G., Flowers, T.J., Jones, M.B., Eds.; Seminar Series 39; Society for Experimental Biology, Cambridge University Press: Cambridge, UK, 1989; pp. 71-93.

73. Alam, S.M. Nutrient uptake by plants under stress conditions. In Handbook of Plant and Crop Stress; Pessarakli, M., Ed.; Marcel Dekker, Inc.: New York, NY, USA, 1999; pp. 285-313.

74. Cornic, G.; Le Gouallec, J.L.; Briantais, J.M.; Hodges, M. Effect of dehydration and high light on photosynthesis of two C3 plants (Phaseolus vulgaris L. and Elatostema repens (Lour.) Hall f.). Planta 1989, 177, 84-90. [CrossRef]

75. Dhindsa, R.S.; Cleland, R.E. Water stress and protein synthesis II. Interaction between water stress, hydrostatic pressure, and abscisic acid on the pattern of protein synthesis in Avena coleoptiles. Plant Physiol. 1975, 55, 782-785. [CrossRef] [PubMed]

76. Ben-Zioni, A.; Itai, C.; Vaadia, Y. Water and salt stresses, kinetin and protein synthesis in tobacco leaves. Plant Physiol. 1967, 42, 361-365. [CrossRef] [PubMed]

77. Yancey, P.H.; Clark, M.E.; Hand, S.C.; Bowlus, R.D.; Somero, G.N. Living with water stress: Evolution of osmolyte systems. Science 1982, 217, 1214-1222. [CrossRef] [PubMed]

78. Pham Thi, A.T.; Borrel-Flood, C.; Da Silva, J.V.; Justin, A.M.; Mazliak, P. Effects of water stress on lipid metabolism in cotton leaves. Phytochemistry 1985, 24, 723-727.

79. Teotia, S.; Singh, D. Oxidative stress in plants and its management. In Approaches to Plant Stress and Their Management; Gaur, R.K., Sharma, P., Eds.; Springer: New Delhi, India, 2014; pp. 227-253.

80. Zhu, J.; Hasegawa, P.M.; Bressan, R.A. Molecular aspects of osmotic stress in plants. Crit. Rev. Plant Sci. 1997, 16, 253-277. [CrossRef]

81. Xiong, L.; Zhu, J.K. Molecular and genetic aspects of plant responses to osmotic stress. Plant Cell Environ. 2002, 25, 131-139. [CrossRef] [PubMed]

82. Vartapetian, B.B.; Jackson, M.B. Plant adaptations to anaerobic stress. Ann. Bot-Lond. 1997, 79 (Suppl. A), 3-20. [CrossRef]

83. Ellis, M.H.; Dennis, E.S.; Peacock, W.J. Arabidopsis roots and shoots have different mechanisms for hypoxic stress tolerance. Plant Physiol. 1999, 119, 57-64. [CrossRef]

84. Vartapetian, B.B.; Andreeva, I.N.; Generozova, I.P.; Polyakova, L.I.; Maslova, I.P.; Dolgikh, Y.I.; Stepanova, A.Y. Functional electron microscopy in studies of plant response and adaptation to anaerobic stress. Ann. Bot-Lond. 2003, 91, 155-172. [CrossRef]

85. Kennedy, R.A.; Rumpho, M.E.; Fox, T.C. Anaerobic metabolism in plants. Plant Physiol. 1992, 100, 1-6. [CrossRef]

86. Bailey-Serres, J.; Chang, R. Sensing and Signalling in response to oxygen deprivation in plants and other organisms. Ann. Bot-Lond. 2005, 96, 507-518. [CrossRef] [PubMed]

87. Blokhina, O.; Virolainen, E.; Fagerstedt, K.V. Antioxidants, oxidative damage and oxygen deprivation stress: A review. Ann. Bot-Lond. 2003, 91, 179-194. [CrossRef] [PubMed]

88. Sunkar, R. MicroRNAs with macro-effects on plant stress responses. Semin. Cell. Dev. Biol. 2010, $21,805-811$. [CrossRef] [PubMed]

89. Mustroph, A.; Lee, S.C.; Oosumi, T.; Zanetti, M.E.; Yang, H.; Ma, K.; Yaghoubi-Masihi, A.; Fukao, T.; Bailey-Serres, J. Cross-kingdom comparison of transcriptomic adjustments to low-oxygen stress highlights conserved and plant-specific responses. Plant Physiol. 2010, 152, 1484-1500. [CrossRef] [PubMed] 
90. Winkler, B.S.; Sauer, M.W.; Starnes, C.A. Modulation of the Pasteur effect in retinal cells: Implications for understanding compensatory metabolic mechanisms. Exp. Eye Res. 2003, 76, 715-723. [CrossRef]

91. Krebs, H.A. The Pasteur effect and the relations between respiration and fermentation. Essays Biochem. 1972, 8, 1-35. [PubMed]

92. Birben, E.; Sahiner, U.M.; Sackesen, C.; Erzurum, S.; Kalayci, O. Oxidative stress and antioxidant defense. World Allergy Organ. J. 2012, 5, 9-19. [CrossRef]

93. Umeda, M.; Uchimiya, H. Differential transcript levels of genes associated with glycolysis and alcohol fermentation in rice plants (Oryza sativa L.) under submergence stress. Plant Physiol. 1994, 106, 1015-1022. [CrossRef] [PubMed]

94. Agarwal, S.; Grover, A. Isolation and transcription profiling of low-O2 stress-associated cDNA clones from the flooding-stress-tolerant FR13A rice genotype. Ann. Bot-Lond. 2005, 96, 831-844. [CrossRef]

95. Sachs, M.M.; Subbaiah, C.C.; Saab, I.N. Anaerobic gene expression and flooding tolerance in maize. J. Exp. Bot. 1996, 47, 1-15. [CrossRef]

96. Chen, L.; Song, Y.; Li, S.; Zhang, L.; Zou, C.; Yu, D. The role of WRKY transcription factors in plant abiotic stresses. Biochim. Biophys. Acta 2012, 1819, 120-128. [CrossRef] [PubMed]

97. Clarkson, D.T.; Carvajal, M.; Henzler, T.; Waterhouse, R.N.; Smyth, A.J.; Cooke, D.T.; Steudle, E. Root hydraulic conductance: Diurnal aquaporin expression and the effects of nutrient stress. J. Exp. Bot. 2000, 51, 342. [CrossRef]

98. Kandlbinder, A.; Finkemeier, I.; Wormuth, D.; Hanitzsch, M.; Dietz, K. The antioxidant status of photosynthesizing leaves under nutrient deficiency: Redox regulation, gene expression and antioxidant activity in Arabidopsis thaliana. Physiol. Plant. 2004, 120, 63-73. [CrossRef] [PubMed]

99. Solecka, D. Role of phenylpropanoid compounds in plant responses to different stress factors. Acta Physiol. Plant. 1997, 19, 257-268. [CrossRef]

100. Dixon, R.A.; Paiva, N.L. Stress-induced phenylpropanoid metabolism. Plant Cell 1995, 7, $1085-1097$. [CrossRef] [PubMed]

101. Liu, J.; Osbourn, A.; Ma, P. MYB transcription factors as regulators of phenylpropanoid metabolism in plants. Mol. Plant 2015, 8, 689-708. [CrossRef] [PubMed]

102. Deng, Y.; Lu, S. Biosynthesis and regulation of phenylpropanoids in plants. Crit. Rev. Plant Sci. 2017, 36, 257-290. [CrossRef]

103. Lillo, C.; Lea, U.S.; Ruoff, P. Nutrient depletion as a key factor for manipulating gene expression and product formation in different branches of the flavonoid pathway. Plant Cell Environ. 2008, 31, 587-601. [CrossRef]

104. Weaver, L.M.; Herrmann, K.M. Dynamics of the shikimate pathway in plants. Trends Plant Sci. 1997, 2, 346-351. [CrossRef]

105. Gershenzon, J. Changes in the levels of plant secondary metabolites under water and nutrient stress. In Phytochemical Adaptations to Stress; Timmermann, B.N., Steelink, C., Loewus, F.A., Eds.; Springer Science+Business Media: New York, NY, USA, 1984.

106. Tewari, R.K.; Kumar, P.; Sharma, P.N. Oxidative stress and antioxidant responses in young leaves of mulberry plants grown under nitrogen, phosphorus or potassium deficiency. J. Integr. Plant Biol. 2007, 49, 313-322. [CrossRef]

107. Yoneyama, K.; Xie, X.; Kim, H.I.; Kisugi, T.; Nomura, T.; Sekimoto, H.; Yokota, T.; Yoneyama, K. How do nitrogen and phosphorus deficiencies affect strigolactone production and exudation? Planta 2012, 235, 1197-1207. [CrossRef] [PubMed]

108. Kovacik, J.; Klejdus, B.; Backor, M.; Repcak, M. Phenylalanine ammonia-lyase activity and phenolic compounds accumulation in nitrogen-deficient Matricaria chamomilla leaf rosettes. Plant Sci. 2007, 172, 393-399. [CrossRef]

109. Shin, R.; Berg, R.H.; Schachtman, D.P. Reactive oxygen species and root hairs in Arabidopsis root response to nitrogen, phosphorus and potassium deficiency. Plant Cell Physiol. 2005, 46, 1350-1357. [CrossRef] [PubMed]

110. Kovacik, J.; Repcak, M.; Kron, I. Nitrogen deficiency induced changes of free amino acids and coumarin contents in the leaves of Matricaria chamomilla. Acta Physiol. Plant. 2006, 28, 159-164. [CrossRef]

111. Chishaki, N.; Horiguchi, T. Responses of secondary metabolism in plants to nutrient deficiency. In Plant Nutrition for Sustainable Food Production and Environment; Ando, T., Fujita, K., Mae, T., Matsumoto, H., Mori, S., Sekiya, J., Eds.; Springer: Dordrecht, The Netherlands, 1997; pp. 341-345. 
112. Bongue-Bartelsman, M.; Phillips, D.A. Nitrogen stress regulates gene expression of enzymes in the flavonoid biosynthetic pathway of tomato. Plant Physiol. Biochem. 1995, 33, 539-546.

113. Stewart, A.J.; Chapman, W.; Jenkins, G.I.; Graham, I.; Martin, T.; Crozier, A. The effect of nitrogen and phosphorus deficiency on flavonol accumulation in plant tissues. Plant Cell Environ. 2001, 24, 1189-1197. [CrossRef]

114. Meyer, S.; Cerovic, Z.G.; Goulas, Y.; Montpied, P.; Demotes-Mainard, S.; Bidel, L.P.R.; Moya, I.; Dreyer, E. Relationships between optically assessed polyphenols and chlorophyll contents, and leaf mass per area ratio in woody plants: A signature of the carbon-nitrogen balance within leaves? Plant Cell Environ. 2006, 29, 1338-1348. [CrossRef]

115. Sharma, P.; Jha, A.B.; Dubey, R.S.; Pessarakli, M. Reactive oxygen species, oxidative damage, and antioxidative defense mechanism in plants under stressful conditions. J. Bot. 2012, 2012, 217037. [CrossRef]

116. Trippi, V.S.; Gidrol, X.; Pradet, A. Effects of oxidative stress caused by oxygen and hydrogen peroxide on energy metabolism and senescence in oat leaves. Plant Cell Physiol. 1989, 30, 157-162. [CrossRef]

117. Casano, L.M.; Gomez, L.D.; Trippi, V.S. Oxygen- and light-induced proteolysis in isolated oat chloroplasts. Plant Cell Physiol. 1990, 31, 377-382.

118. Casano, L.M.; Martin, M.; Sabater, B. Sensitivity of superoxide dismutase transcript levels and activities to oxidative stress is lower in mature-senescent than in young barley leaves. Plant Physiol. 1994, 106, 1033-1039. [CrossRef] [PubMed]

119. Kotak, S.; Larkindale, J.; Lee, U.; von Koskull-DÖring, P.; Vierling, E.; Scharf, K. Complexity of the heat stress response in plants. Curr. Opin. Plant Biol. 2007, 10, 310-316. [CrossRef] [PubMed]

120. Wahid, A.; Gelani, S.; Ashraf, M.; Foolad, M.R. Heat tolerance in plants: An overview. Environ. Exp. Bot. 2007, 61, 199-223. [CrossRef]

121. Hasanuzzaman, M.; Nahar, K.; Fujita, M. Extreme temperature responses, oxidative stress and antioxidant defense in plants. In Abiotic Stress_Plant Responses and Applications in Agriculture; Vahdati, K., Leslie, C., Eds.; InTech: Rijeka, Croatia, 2013; pp. 169-205.

122. Guilioni, L.; Wery, J.; Tardieu, F. Heat stress-induced abortion of buds and flowers in pea: Is sensitivity linked to organ age or to relations between reproductive organs? Ann. Bot-Lond. 1997, 80, 159-168. [CrossRef]

123. Wollenweber, B.; Porter, J.R.; Schellberg, J. Lack of interaction between extreme high-temperature events at vegetative and reproductive growth stages in wheat. J. Agron. Crop Sci. 2003, 189, 142-150. [CrossRef]

124. Simões-Araújo, J.L.; Rumjanek, N.G.; Margis-Pinheiro, M. Small heat shock proteins genes are differentially expressed in distinct varieties of common bean. Braz. J. Plant Physiol. 2003, 15, 33-41. [CrossRef]

125. Bohnert, H.J.; Nelson, D.E.; Jensen, R.G. Adaptations to environmental stresses. Plant Cell 1995, 7, $1099-1111$. [CrossRef] [PubMed]

126. Hare, P.D.; Cress, W.A.; Van Staden, J. Dissecting the roles of osmolyte accumulation during stress. Plant Cell Environ. 1998, 21, 535-553. [CrossRef]

127. Sakamoto, A.; Murata, N. The role of glycine betaine in the protection of plants from stress: Clues from transgenic plants. Plant Cell Environ. 2002, 25, 163-171. [CrossRef]

128. Salvucci, M.E.; Crafts-Brandner, S.J. Inhibition of photosynthesis by heat stress: The activation state of Rubisco as a limiting factor in photosynthesis. Physiol. Plant. 2004, 120, 179-186. [CrossRef]

129. Hasanuzzaman, M.; Nahar, K.; Alam, M.M.; Roychowdhury, R.; Fujita, M. Physiological, biochemical, and molecular mechanisms of heat stress tolerance in plants. Int. J. Mol. Sci. 2013, 14, 9643-9684. [CrossRef] [PubMed]

130. Hasanuzzaman, M.; Hossain, M.A.; da Silva, J.A.T.; Fujita, M. Plant response and tolerance to abiotic oxidative stress: Antioxidant defense is a key factor. In Crop Stress and Its Management: Perspectives and Strategies; Venkateswarlu, B., Shanker, A.K., Shanker, C., Maheswari, M., Eds.; Springer: Dordrecht, The Netherlands, 2012; pp. 261-315.

131. Yoshikawa, T.; Naito, Y. What is oxidative stress? Jpn. Med. Assoc. J. 2002, 124, 1549-1553.

132. Lushchak, V.I. Adaptive response to oxidative stress: Bacteria, fungi, plants and animals. Comp. Biochem. Phys. C 2011, 153, 175-190. [CrossRef] [PubMed]

133. Mahajan, S.; Tuteja, N. Cold, salinity and drought stresses: An overview. Arch. Biochem. Biophys. 2005, 444, 139-158. [CrossRef] [PubMed]

134. Neill, S.; Desikan, R.; Hancock, J. Hydrogen peroxide signalling. Curr. Opin. Plant Biol. 2002, 5, 388-395. [CrossRef] 
135. Yan, J.; Tsuichihara, N.; Etoh, T.; Iwai, S. Reactive oxygen species and nitric oxide are involved in ABA inhibition of stomatal opening. Plant Cell Environ. 2007, 30, 1320-1325. [CrossRef]

136. Jabs, T. Reactive oxygen intermediates as mediators of programmed cell death in plants and animals. Biochem. Pharmacol. 1999, 57, 231-245. [CrossRef]

137. Bethke, P.C.; Jones, R.L. Cell death of barley aleurone protoplasts is mediated by reactive oxygen species. Plant J. 2001, 25, 19-29. [CrossRef]

138. Joo, J.H.; Bae, Y.S.; Lee, J.S. Role of auxin-induced reactive oxygen species in root gravitropism. Plant Physiol. 2001, 126, 1055-1060. [CrossRef]

139. Mittler, R. ROS are good. Trends Plant Sci. 2017, 22, 11-19. [CrossRef]

140. Suzuki, N.; Mittler, R. Reactive oxygen species and temperature stresses: A delicate balance between signaling and destruction. Physiol. Plant. 2006, 126, 45-51. [CrossRef]

141. Sun, B.; Jing, Y.; Chen, K.; Song, L.; Chen, F.; Zhang, L. Protective effect of nitric oxide on iron deficiency-induced oxidative stress in maize (Zea mays). J Plant Physiol. 2007, 536-543. [CrossRef] [PubMed]

142. Gill, S.S.; Tuteja, N. Reactive oxygen species and antioxidant machinery in abiotic stress tolerance in crop plants. Plant Physiol. Biochem. 2010, 48, 909-930. [CrossRef] [PubMed]

143. Das, K.; Roychoudhury, A. Reactive oxygen species (ROS) and response of antioxidants as ROS-scavengers during environmental stress in plants. Front. Environ. Sci. 2014, 2,1-13. [CrossRef]

144. Zaefyzadeh, M.; Quliyev, R.A.; Babayeva, S.M.; Abbasov, M.A. The effect of the interaction between genotypes and drought stress on the superoxide dismutase and chlorophyll content in durum wheat landraces. Turk. J. Biol. 2009, 33, 1-7.

(C) 2019 by the authors. Licensee MDPI, Basel, Switzerland. This article is an open access article distributed under the terms and conditions of the Creative Commons Attribution (CC BY) license (http://creativecommons.org/licenses/by/4.0/). 